\title{
Measurement-based modeling of bromine chemistry in the boundary layer: 1. Bromine chemistry at the Dead Sea
}

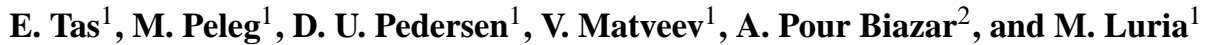 \\ ${ }^{1}$ Institute of Earth Sciences, Hebrew University of Jerusalem, Israel \\ ${ }^{2}$ Earth System Science Center, University of Alabama in Huntsville, Huntsvile, AL 35899, USA
}

Received: 13 February 2006 - Published in Atmos. Chem. Phys. Discuss.: 19 June 2006

Revised: 8 November 2006 - Accepted: 10 November 2006 - Published: 14 December 2006

\begin{abstract}
The Dead Sea is an excellent natural laboratory for the investigation of Reactive Bromine Species (RBS) chemistry, due to the high RBS levels observed in this area, combined with anthropogenic air pollutants up to several ppb. The present study investigated the basic chemical mechanism of RBS at the Dead Sea using a numerical one-dimensional chemical model. Simulations were based on data obtained from comprehensive measurements performed at sites along the Dead Sea. The simulations showed that the high BrO levels measured frequently at the Dead Sea could only partially be attributed to the highly concentrated $\mathrm{Br}^{-}$present in the Dead Sea water. Furthermore, the RBS activity at the Dead Sea cannot solely be explained by a pure gas phase mechanism. This paper presents a chemical mechanism which can account for the observed chemical activity at the Dead Sea, with the addition of only two heterogeneous processes: the "Bromine Explosion" mechanism and the heterogeneous decomposition of $\mathrm{BrONO}_{2}$. Ozone frequently dropped below a threshold value of $\sim 1$ to 2 ppbv at the Dead Sea evaporation ponds, and in such cases, $\mathrm{O}_{3}$ became a limiting factor for the production of $\mathrm{BrO}_{\mathrm{x}}(\mathrm{BrO}+\mathrm{Br})$. The entrainment of $\mathrm{O}_{3}$ fluxes into the evaporation ponds was found to be essential for the continuation of RBS activity, and to be the main reason for the jagged diurnal pattern of $\mathrm{BrO}$ observed in the Dead Sea area, and for the positive correlation observed between $\mathrm{BrO}$ and $\mathrm{O}_{3}$ at low $\mathrm{O}_{3}$ concentrations. The present study has shown that the heterogeneous decomposition of $\mathrm{BrONO}_{2}$ has a great potential to affect the RBS activity in areas influenced by anthropogenic emissions, mainly due to the positive correlation between the rate of this process and the levels of $\mathrm{NO}_{2}$. Further investigation of the influence of the decomposition of $\mathrm{BrONO}_{2}$ may be especially important in understanding the RBS activity at mid-latitudes.
\end{abstract}

Correspondence to: E. Tas

(erann@pob.huji.ac.il)

\section{Introduction}

It has become increasingly clear that Reactive Halogen Species (RHS) have a significant potential to affect tropospheric chemistry (Von Glasow et al., 2004). This is mainly because RHS can destroy ozone in the boundary layer via catalytic chemical cycles. Several observations have detected a sharp depletion in boundary layer ozone concentrations, from normal values between 30 and $40 \mathrm{ppb}$ to below detection limits $(\leq 2 \mathrm{ppb})$ in the polar regions during springtime (Tuckermann et al., 1997; Hausmann and Platt, 1994; Barrie et al., 1988; Kreher et al., 1997; Murayama et al., 1992). It has been shown that elevated $\mathrm{BrO}$ levels of up to $30 \mathrm{ppt}$, are concurrent with episodes of boundary layer ozone destruction (Platt and Honinger, 2003).

It has been recognized that RHS may also lead to boundary layer $\mathrm{O}_{3}$ destruction at mid latitudes. This was first observed at the Dead Sea valley in Israel (Matveev et al., 2001; Hebestreit et al., 1999), based on an obvious anticorrelation between ozone and $\mathrm{BrO}$ during ozone depletion events. In these measurements, very high $\mathrm{BrO}$ levels above $150 \mathrm{ppt}$ were detected together with daytime depletion of $\mathrm{O}_{3}$, from levels greater than $120 \mathrm{ppb}$ to below the detection limit of the instrument ( $\leq 2 \mathrm{ppb}$ ). All subsequent measurement campaigns performed at the Dead Sea (Tas et al., 2005; Matveev et al., 2001; Hebestreit et al., 1999; Stutz et al., 1999) have shown the presence of elevated BrO levels (Tas et al., 2005, 2003; Matveev et al., 2001; Hebestreit et al., 1999). Evidence for RBS activity was also found at other mid-latitude locations, e.g., at the Great Salt Lake, Utah (Stutz et al., 2002), north of the Canary Islands (Leser et al., 2003) and at Salar de Uyuni, Bolivia (Honninger et al., 2004).

Previous research on Reactive Bromine species (RBS) has been conducted either at the polar regions, which have very low anthropogenic pollution levels or even pristine conditions (Ridley and Orlando, 2003; Tuckermann et al., 1997; Hausmann and Platt, 1994; Beine et al., 1997), or at

Published by Copernicus GmbH on behalf of the European Geosciences Union. 
mid-latitude locations with low concentrations of RBS (Stutz et al., 2002; Leser et al., 2003; Honninger et al., 2004). At the Dead Sea area, very elevated concentrations of $\mathrm{BrO}$ (up to more than $150 \mathrm{pptv}$ ) are frequently observed (Tas et al., 2005), while in general, photochemical air pollution in this area can be characterized by average levels of $\mathrm{NO}_{2}$ and $\mathrm{SO}_{2}$ around several ppb. Therefore, the Dead Sea basin provides a unique natural laboratory for investigating the interaction between RBS and photochemical pollutants.

The present study focuses on RBS activity in the Dead Sea area of Israel. The Dead Sea Valley has unique geophysical conditions, being the deepest land area on the face of earth, situated about $400 \mathrm{~m}$ below sea level, between $31^{\circ} 00^{\prime} \mathrm{N}$ and $31^{\circ} 50^{\prime} \mathrm{N}-035^{\circ} 30^{\prime} \mathrm{E}$. The Dead Sea is one of the most saline lakes in the world with $5.6 \mathrm{~g}$ bromide/ $/$ and $225 \mathrm{~g}$ chloride/l (Niemi et al., 1997). The bromine content at the Dead Sea is higher than in normal ocean water (Sverdrup et al., 1942), higher than at the Great Salt Lake, Utah (Stutz et al., 2002) and Salar de Uyuni, Bolivia (Honninger et al., 2004) by factors of 86,134 , and 19 to 400 , respectively. The $\mathrm{Br} / \mathrm{Cl}$ ratio at the Dead Sea is higher than in normal ocean water and the Great Salt Lake, by factors of about 7.5 and 36, respectively.

A number of studies (Hebestreit et al., 1999; Matveev et al., 2001) performed at the Dead Sea have clearly shown the role of $\mathrm{BrO}_{\mathrm{x}}(\mathrm{BrO}+\mathrm{Br})$ in causing ozone depletion. Two main chemical mechanisms have been proposed as being responsible for the catalytic destruction of ozone at the boundary layer via the recycling of $\mathrm{BrO}_{\mathrm{x}}$ (Wayne et al., 1995).

The first mechanism is driven by the self reaction of $\mathrm{BrO}$ and the photolysis of $\mathrm{Br}_{2}$ :

Cycle 1 (BrO-cycle)

$$
\begin{aligned}
\mathrm{Br}_{2}+h v & \rightarrow 2 \mathrm{Br} \\
\left(\mathrm{Br}+\mathrm{O}_{3}\right. & \left.\rightarrow \mathrm{BrO}+\mathrm{O}_{2}\right) \times 2 \\
\mathrm{BrO}+\mathrm{BrO} & \rightarrow 2 \mathrm{Br}+\mathrm{O}_{2} \\
& \rightarrow \mathrm{Br}_{2}+\mathrm{O}_{2}
\end{aligned}
$$

$2 \mathrm{O}_{3} \stackrel{\mathrm{BrO}_{\mathrm{x}}}{\longrightarrow} 3 \mathrm{O}_{2}$

The second mechanism is initiated by the hydroperoxyl radical as shown below:

Cycle 2 (HOBr-cycle)

$\mathrm{BrO}+\mathrm{HO}_{2} \rightarrow \mathrm{HOBr}+\mathrm{O}_{2}$

$\mathrm{HOBr}+h v \rightarrow \mathrm{OH}+\mathrm{Br}$

$\mathrm{Br}+\mathrm{O}_{3} \rightarrow \mathrm{BrO}+\mathrm{O}_{2}$

$\overline{\mathrm{HO}_{2}+\mathrm{O}_{3} \stackrel{\mathrm{HOBr}, \mathrm{BrOx}}{\longrightarrow} \mathrm{OH}+2 \mathrm{O}_{2}}$
Even so, the main chemical mechanisms that take place in this area are still unknown. One of the widely recognized mechanisms that participate in the RBS chemistry is the heterogeneous decomposition of $\mathrm{BrONO}_{2}$ (Hanson and Ravishankara, 1995; Hanson et al., 1996; Sander et al., 1999). Since $\mathrm{NO}_{2}$ concentrations at the Dead Sea are on the order of several ppb, higher than at the other sites where $\mathrm{BrO}$ was identified, the formation and subsequent heterogeneous decomposition of $\mathrm{BrONO}_{2}$ (Reaction $\mathrm{H1}$ ) was suggested as an important process for recycling RBS (Tas et al., 2005) in this area

$\mathrm{BrONO}_{2}+\mathrm{H}_{2} \mathrm{O} \rightarrow \mathrm{HOBr}+\mathrm{HNO}_{3}$

Previous research has identified the "Bromine Explosion" mechanism (Reaction H2) as an important process releasing Br into the gas phase (Fan and Jacob, 1992; Vogt et al., 1996; Mozurkewich et al., 1995; Tang and McConnell, 1996; Platt and Moortgat, 1999). The "Bromine Explosion" has been suggested as the most likely process of $\mathrm{Br}$ release into the gas phase at the Dead Sea (Tas et al., 2005, 2003; Matveev et al., 2001)

$\mathrm{HOBr}+\mathrm{H}^{+}+\mathrm{Br}^{-} \rightarrow \mathrm{Br}_{2}+\mathrm{H}_{2} \mathrm{O}$

The reasons for this were the high $\left[\mathrm{Br}^{-}\right]$content, the high ratio of $\left[\mathrm{Br}^{-}\right] /\left[\mathrm{Cl}^{-}\right]$and the high levels of $\mathrm{BrO}$ frequently measured at the Dead Sea (Tas et al., 2005, 2003; Matveev et al., 2001)

This paper is the first to present a basic chemical mechanism that can explain the fundamental chemical activity of RBS observed at the Dead Sea. This objective was achieved with a one dimensional model, which uses an explicit chemical mechanism, in combination with data obtained from comprehensive measurement campaigns. The present study focuses on the main factors and processes which lead to the extraordinarily high $\mathrm{BrO}$ levels, the unique $\mathrm{BrO}$ diurnal profile obtained at the Dead Sea, and the efficient ozone destruction via $\mathrm{BrO}_{\mathrm{x}}$ production.

\section{Experimental}

\subsection{Model description}

\subsubsection{Basic model}

The core of the research analysis was done by a onedimensional Chemical Transport Model, UAHCTM_1D (Biazar, 1995). This model includes an explicit gas phase chemical mechanism and takes into account the vertical motion of the different species based on diffusion and advection calculations and on deposition velocity values.

The model calculates the changes in the mixing ratio, $C_{i}$, of species $\mathrm{i}$ in the gas phase with time $(t)$ according to Eq. (1):

$$
\frac{\partial C_{i}}{\partial t}=-w \frac{\partial C_{i}}{\partial z}+\frac{\partial}{\partial z}\left[K_{(z)} \frac{\partial C_{i}}{\partial z}\right]+q_{i}+p_{i}-C_{i} l_{i}
$$


Table 1. Reactions in the gas phase.

\begin{tabular}{|c|c|c|c|}
\hline $\begin{array}{l}\text { Reaction } \\
\text { No. }\end{array}$ & Gas phase reactions & 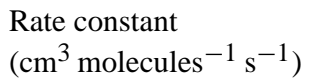 & Reference \\
\hline (G1) & $\mathrm{Br}+\mathrm{O}_{3} \rightarrow \mathrm{BrO}+\mathrm{O}_{2}$ & $1.2 \times 10^{-12}$ & 1 \\
\hline (G2) & $\mathrm{BrO}+\mathrm{BrO} \rightarrow \mathrm{Br}+\mathrm{Br}+\mathrm{O}_{2}$ & $2.7 \times 10^{-12}$ & 1 \\
\hline (G3) & $\mathrm{BrO}+\mathrm{BrO} \rightarrow \mathrm{Br}_{2}+\mathrm{O}_{2}$ & $4.8 \times 10^{-13}$ & 1 \\
\hline (G4) & $\mathrm{Br}+\mathrm{HO}_{2} \rightarrow \mathrm{HBr}+\mathrm{O}_{2}$ & $2.0 \times 10^{-12}$ & 1 \\
\hline (G5) & $\mathrm{BrO}+\mathrm{HO}_{2} \rightarrow \mathrm{HBr}+\mathrm{O}_{3}$ & $2.3 \times 10^{-13}$ & 1,2 \\
\hline (G6) & $\mathrm{BrO}+\mathrm{HO}_{2} \rightarrow \mathrm{HOBr}+\mathrm{O}_{2}$ & $2.3 \times 10^{-11}$ & 1,2 \\
\hline (G7) & $\mathrm{BrO}+\mathrm{OH} \rightarrow \mathrm{Br}+\mathrm{HO}_{2}$ & $4.1 \times 10^{-11}$ & $3,4,5$ \\
\hline (G8) & $\mathrm{BrO}+\mathrm{OH} \rightarrow \mathrm{HBr}+\mathrm{O}_{2}$ & $4.1 \times 10^{-13}$ & 3 \\
\hline (G9) & $\mathrm{Br}_{2}+\mathrm{OH} \rightarrow \mathrm{HOBr}+\mathrm{Br}$ & $4.5 \times 10^{-11}$ & 1 \\
\hline (G10) & $\mathrm{HBr}+\mathrm{OH} \rightarrow \mathrm{H}_{2} \mathrm{O}+\mathrm{Br}$ & $1.1 \times 10^{-11}$ & 1 \\
\hline (G11) & $\mathrm{Br}+\mathrm{NO}_{3} \rightarrow \mathrm{BrO}+\mathrm{NO}_{2}$ & $1.6 \times 10^{-11}$ & 1 \\
\hline (G12) & $\mathrm{BrO}+\mathrm{NO}_{3} \rightarrow \mathrm{BrOO}+\mathrm{NO}_{2}$ & $1.0 \times 10^{-12}$ & 1 \\
\hline (G13) & $\mathrm{OBrO}+\mathrm{NO} \rightarrow \mathrm{BrO}+\mathrm{NO}_{2}$ & $1.8 \times 10^{-12}$ & 6 \\
\hline (G14) & $\mathrm{BrO}+\mathrm{NO}_{2} \stackrel{M}{\longrightarrow} \mathrm{BrONO}_{2}^{\mathrm{a}}$ & $5.7 \times 10^{-12}$ & 1 \\
\hline (G15) & $\mathrm{Br}+\mathrm{NO}_{2} \stackrel{M}{\longrightarrow} \mathrm{BrNO}_{2}^{\mathrm{a}}$ & $6.5 \times 10^{-12}$ & 1 \\
\hline (G16) & $\mathrm{BrO}+\mathrm{NO} \rightarrow \mathrm{Br}+\mathrm{NO}_{2}$ & $2.1 \times 10^{-11}$ & 1 \\
\hline (G17) & $\mathrm{Br}+\mathrm{CH}_{2} \mathrm{O} \rightarrow \mathrm{HBr}+\mathrm{HCO}$ & $1.1 \times 10^{-12}$ & 1 \\
\hline (G18) & $\mathrm{Br}+\mathrm{C}_{2} \mathrm{H}_{2} \rightarrow \mathrm{CH}_{2} \mathrm{Br}$ & $2.6 \times 10^{-14}$ & 1 \\
\hline (G19) & $\mathrm{Br}+\mathrm{C}_{2} \mathrm{H}_{4} \rightarrow \mathrm{BrC}_{2} \mathrm{H}_{4}$ & $1.3 \times 10^{-13}$ & 1 \\
\hline$(\mathrm{G} 20)$ & $\mathrm{Br}+\mathrm{CH}_{3} \mathrm{CHO} \rightarrow \mathrm{HBr}+\mathrm{CH}_{3} \mathrm{CO}$ & $3.9 \times 10^{-12}$ & 1 \\
\hline (G21) & $\mathrm{Br}+\mathrm{CH}_{3} \mathrm{O}_{2} \rightarrow \mathrm{BrO}+\mathrm{CH}_{3} \mathrm{O}$ & $2.5 \times 10^{-14}$ & 7 \\
\hline$(\mathrm{G} 22)$ & $\mathrm{Br}+\mathrm{C}_{3} \mathrm{H}_{6} \rightarrow \mathrm{HBr}+\mathrm{C}_{3} \mathrm{H}_{5}^{\mathrm{b}}$ & $1.2 \times 10^{-14}$ & 1 \\
\hline (G23) & $\mathrm{Br}+\mathrm{C}_{3} \mathrm{H}_{6} \stackrel{M}{\longrightarrow} \mathrm{BrC}_{3} \mathrm{H}_{6}^{\mathrm{b}}$ & $3.6 \times 10^{-12}$ & 1 \\
\hline (G24) & $\mathrm{BrO}+\mathrm{CH}_{3} \mathrm{O}_{2} \rightarrow \mathrm{Br}+\mathrm{CH}_{3} \mathrm{O}+\mathrm{O}_{2}$ & $0.9 \times 10^{-12}$ & 8 \\
\hline (G25) & $\mathrm{BrO}+\mathrm{CH}_{3} \mathrm{O}_{2} \rightarrow \mathrm{OBrO}+\mathrm{CH}_{3} \mathrm{O}$ & $0.9 \times 10^{-12}$ & 8 \\
\hline (G26) & $\mathrm{BrO}+\mathrm{CH}_{3} \mathrm{O}_{2} \rightarrow \mathrm{HOBr}+\mathrm{CH}_{2} \mathrm{O}_{2}$ & $4.6 \times 10^{-12}$ & 8 \\
\hline
\end{tabular}

${ }^{1}$ Atkinson et al. (2003); ${ }^{2}$ Bloss et al. (2002); ${ }^{3}$ Bedjanian et al. (2001); ${ }^{4}$ Gilles et al. (2001); ${ }^{5}$ Atkinson et al. (2004); ${ }^{6}$ Li and Tao (1999); ${ }^{7}$ Stutz et al. (1999); ${ }^{8}$ Aranda et al. (1997); ${ }^{a}$ Pressure dependent reactions; Calculated for $800 \mathrm{~mm} \mathrm{Hg}$ and $305^{\circ} \mathrm{K}$. ${ }^{\mathrm{b}}$ Insignificant

where $w$ is the vertical wind speed component, $z$ indicates the vertical height, and $K_{(z)}$ is the exchange coefficient at height $z$. The two first right hand side terms are the advection and diffusion terms, respectively. $q_{i}$ is the sum of emissions fluxes or advection fluxes for species i. $p_{i}$ and $C_{i} l_{i}$ are the gas phase chemical production and loss, respectively. The fluxes through the top of the model, the surface emissions and the surface deposition flux are included in the model as boundary conditions of the second order partial differential equation term.

For the present study the model used 27 levels from the surface to a height of $10 \mathrm{~km}$ with variable spacing in order to represent the boundary layer with greater vertical resolution. Four grid points were included between heights of 1 and $10 \mathrm{~m}$ and 7 grid points were included between heights of $10 \mathrm{~m}$ and $100 \mathrm{~m}$ and between $100 \mathrm{~m}$ and $1000 \mathrm{~m}$. The model results are presented only for a height of $2 \mathrm{~m}$, approximately the height at which the chemical parameters were measured (Sect. 2.3).
The basic photochemical processes described by 166 gas-phase reactions were based on the Trainer mechanism (Trainer et al., 1987), which was updated according to Atkinson et al. (2003). Thirty one reactions were added to describe the bromine gas phase mechanism (Tables 1 and 2). The deposition velocities of the bromine species that had a significant influence on the results of the present simulations are listed in Table 3. The velocities for $\mathrm{NO}, \mathrm{NO}_{2}, \mathrm{C}_{4} \mathrm{H}_{6} \mathrm{O}$ (methacrolien), $\mathrm{C}_{4} \mathrm{H}_{6} \mathrm{O}$ (methyl vinyl ketone) and PAN (peroxyacetyl nitrate) were calculated according to Trainer et al. (1987). Deposition velocities for $\mathrm{H}_{2} \mathrm{O}_{2}, \mathrm{CH} 3 \mathrm{OOH}$, $\mathrm{CH} 3 \mathrm{O}_{2}$ and $\mathrm{CH}_{2} \mathrm{O}$ were calculated in the same way based on values from Sander and Crutzen (1996).

The rate constant for each photochemical reaction was calculated at a time resolution of $15 \mathrm{~min}$ by integrating over the relevant wavelengths, using Eq. (2):

$k_{p}=\int_{\lambda} F(\lambda) \sigma(\lambda) \phi(\lambda) d \lambda$ 
Table 2. Photolysis reactions of Bromine species and their average daytime rate constants in the gas phase calculated for $15^{\circ}$ zenith angle and clear sky at the Dead Sea (31.0 latitude).

\begin{tabular}{llll}
\hline $\begin{array}{l}\text { Reaction } \\
\text { No. }\end{array}$ & Gas phase reactions & $\begin{array}{l}\text { Gas phase } \\
\text { reactions }\end{array}$ & Reference \\
\hline$(\mathrm{GP} 1)$ & $\mathrm{Br} 2 \stackrel{h v}{\longrightarrow} \mathrm{Br}+\mathrm{Br}$ & $3.1 \times 10^{-02}$ & 1 \\
$(\mathrm{GP} 2)$ & $\mathrm{BrO} \stackrel{h v}{\longrightarrow} \mathrm{Br}+\mathrm{O}_{3}$ & $3.8 \times 10^{-02}$ & 1 \\
$(\mathrm{GP} 3)$ & $\mathrm{HOBr} \stackrel{h v}{\longrightarrow} \mathrm{Br}+\mathrm{OH}$ & $2.5 \times 10^{-03}$ & 1 \\
$(\mathrm{GP} 4)$ & $\mathrm{BrONO}_{2} \stackrel{h v}{\longrightarrow} \mathrm{Br}+\mathrm{NO}_{3}$ & $1.6 \times 10^{-03}$ & 2 \\
$(\mathrm{GP} 5)$ & $\mathrm{BrNO}_{2} \stackrel{h v}{\longrightarrow} \mathrm{Br}+\mathrm{NO}_{2}^{\mathrm{a}}$ & $2.2 \times 10^{-03}$ & 3 \\
$(\mathrm{GP} 5)$ & $\mathrm{OBrO}_{2 v}^{\longrightarrow} \mathrm{BrO}+\mathrm{O}_{3}$ & $1.3 \times 10^{-00}$ & 1 \\
\hline
\end{tabular}

${ }^{1}$ Atkinson et al. (2003); ${ }^{2}$ Atkinson et al. (2002); $\phi$ was taken from Harwood et al. (1998); ${ }^{3}$ Stutz et al. (1999); ${ }^{\text {E}}$ Estimated from redshifted ClONO absorption cross-section by $50 \mathrm{~nm}$.

where $\lambda$ is the wavelength, $\phi$ is the quantum yield, $\sigma$ is the absorption coefficient and $F$ is the actinic flux. The actinic flux was calculated by running the Tropospheric Ultraviolet \& Visible Radiation model (Madronich et al., 1998). All simulations were restricted to clear sky cases, based on global and ultraviolet radiation measurement data. The maximal error in actinic flux calculations is estimated to be $16 \%$ for the short UV range $(<310 \mathrm{~nm})$ and less for longer wave lengths (Schwander et al., 1997; Erlick and Frederick, 1998; Ruggaber et al., 1994).

Since the model used in the present study is onedimensional, it cannot account for external advection of chemical pollutants, and it was therefore necessary to add horizontal fluxes. The fluxes were determined based on simulations performed for those days on which no significant activity of RHS was detected at the Dead Sea evaporation ponds (Sect. 2.3). In these preliminary simulations the RBS mechanism was not included, and the results provided a reasonable agreement between the measured and simulated time series of ground level $\mathrm{NO}_{\mathrm{x}}$ and hydrocarbons for these days. Once these fluxes were determined for those days in which no RBS activity was observed, the same fluxes were included in all simulations with the addition of the RBS mechanism. The magnitude of the fluxes at each height was estimated based on the vertical profiles that were obtained during the preliminary simulations. This procedure was used in order to include fluxes for $\mathrm{NO}, \mathrm{NO}_{2}$ and 13 different hydrocarbons species, at heights between ground level and the base of the planetary boundary layer. A very small flux of $\mathrm{Br}_{2}$ of 10 molecules $\mathrm{cm}^{-2} \mathrm{~s}^{-1}$ was added for initiation of the bromine species activity, from ground level upwards.

Necessary meteorological parameters, including the planetary boundary height, representative of real conditions were obtained by running the 1_d Meteorological model (McNider
Table 3. Deposition velocities for some bromine species.

\begin{tabular}{ll}
\hline Species & $v_{d} \mathrm{cms}^{-1}$ \\
\hline $\mathrm{HOBr}$ & $0.2^{\mathrm{a}}$ \\
$\mathrm{HBr}$ & $0.65^{\mathrm{a}}$ \\
$\mathrm{BrONO}_{2}$ & $0.18^{\mathrm{b}}$ \\
$\mathrm{BrNO}_{2}$ & $0.18^{\mathrm{b}}$ \\
\hline
\end{tabular}

a Values were determined based on Sander and Crutzen (1996).

b Values similar to those of $\mathrm{NO}_{2}$ were used.

and Pielke, 1981). The meteorological conditions, fluxes, solar data and heterogeneous parameterizations were updated every $15 \mathrm{~min}$ in all simulations.

All features described in the basic model sections were an integral part of all the model simulations. However, the basic model was unable to account for the observed RBS activity without the inclusion of heterogeneous processes and ozone fluxes.

\subsubsection{Heterogeneous processes}

As described later, the model simulations could not duplicate the observed chemical effects of the bromine species by including only a gas phase mechanism in the model. Two heterogeneous processes, the heterogeneous decomposition of $\mathrm{BrONO}_{2}(\mathrm{H} 1)$ and the "Bromine Explosion" Mechanism $(\mathrm{H} 2)$, were the only additions to the mechanism, significantly improving the agreement between measurements and simulations (Sect. 3.1.2).

These two reactions were added to the basic model using parameterization for their first order rate constant, according to Eq. (3):

$R=(\gamma<c>A) / 4$

where $\mathrm{R}$ is the rate coefficient, $\gamma$ is the uptake coefficient, $<c>$ is the mean thermal velocity and $A$ is particle surface area per unit volume.

The basic physical assumptions are that Reaction (H1) takes place mainly on sulfate aerosols, while Reaction (H2) takes place mainly in the sea salt aerosols present over the water. The first assumption is based on the relatively high efficiency of the heterogeneous decomposition of $\mathrm{BrONO}_{2}$ on sulfate aerosols (Von Glasow et al., 2002; Hanson et al., 1996; Hanson and Ravishankara, 1995) together with the high levels of sulfate aerosols measured at the Dead Sea, averaging $\sim 8 \mu \mathrm{g} \mathrm{m}^{-3}$. This value is very similar to other values that were reported for this area (Andreae et al., 2002; Wanger et al., 2000; Formenti et al., 2001).

Studies have shown that the dependence of the rate of Reaction (H1) on atmospheric conditions is essentially very weak (Hanson et al., 1996). The uptake coefficient for this reaction is only slightly dependent on particle size, composition of sulfuric acid, and temperature (Hanson et al., 1996; 
Hanson and Ravishankara, 1995). Further, the heterogeneous decomposition rate of $\mathrm{BrONO}_{2}$ is very efficient under dry conditions (Hanson and Ravishankara, 1995), such as exist at the Dead Sea. Based on this information it was concluded that it was justified to include Reaction (H1) in the model by a parameterization.

The total surface area of sulfate aerosols was determined based on direct measurements of sulfate aerosols at the Dead Sea (Matveev et al., 2001) and the average value for the density and radius of sulfate aerosols. Values between 50$65 \mu \mathrm{g}^{2} / \mathrm{cm}^{3}$ were used for the total surface area of sulfate aerosols. A value of 0.75 was assumed for the uptake coefficient $\gamma$ (Reaction H1) based on literature data (Atkinson et al., 2004; Hanson et al., 1996) and a comparison of model simulations with relevant measurements.

Reaction (H2), the "Bromine Explosion", is the most likely chemical mechanism for the release of bromine into the gas phase at the Dead Sea (Matveev et al., 2001; Tas et al., 2005). In the present simulation study, it was assumed that $\mathrm{Br}_{2}$ was released solely from the sea salt aerosols. This is not necessarily true, since it is also possible that part of the $\mathrm{Br}_{2}$ is released directly from the water or salt surfaces (Sect. 3.1.2), or from sulfate aerosols (Von Glasow et al., 2002; Fan and Jacob, 1992). As supported by the model results, the release from sea salt aerosols is assumed to be the major contributor because there were very limited solid salt depositions in the investigation region.

The rate constant for Reaction (H2) was determined based on comparison of model simulations and measurements. The rate of Reaction (H2) was obtained as the only degree of freedom in the structure of the model. A range of values for Reaction (H2) was tested, and the best agreement between simulations and measurements was obtained for a daily average value of $\sim 1.35 \times 10^{-6} \mathrm{ppb} / \mathrm{s}$. This final value was in good agreement with values calculated from the literature (e.g., Michalowski et al., 2000), and was used for the model simulations. The model simulations suggest that the results are relatively insensitive to the timing of changes of the rate of Reaction (H2) (Sect. 3.1.2).

Sea salt aerosol concentrations are a strong function of surface wind speed. This relationship was thus included for each 15 min update interval in the parameterization of the rate of Reaction (H2), according to Eq. (4) (Gong et al., 1997; Gras and Ayers, 1983):

$\ln \chi=\ln (b)+a U_{10}$

where $\chi$-ambient sea salt aerosol concentration; $\mathrm{U}_{10}$ - wind speed measured at $10 \mathrm{~m}$ height over the evaporation ponds; $\mathrm{a}, \mathrm{b}$ - empirical parameters determined based on Gong et al. (1997). This parameterization was included mainly in order to examine its importance in the area under investigation. The effect of this parameterization on the results was found to be negligible (Sect. 3.1.2).

The bromide concentrations in the sea water at the study site increases from north to south, and it is, therefore, pos- sible that different wind directions may have led to different $\mathrm{BrO}$ concentrations. The relation between wind direction and $\mathrm{BrO}$ concentrations was therefore analyzed based on measurements from the entire campaign using the magnitude $\overline{\mathrm{BrO}} \cdot \frac{n_{t}(i)}{n(i)}$, where $n_{t}(i)=$ time percentage in which positive $\mathrm{BrO}$ concentrations were measured for a wind direction (i); $n_{(i)}=$ time percentage for which wind direction (i) was measured during daytime; $\overline{\mathrm{BrO}}=$ average daytime $\mathrm{BrO}$ concentrations obtained for wind direction (i). This relation was parameterized into the rate of Reaction (H2) for each update time of the model. The basic assumption was that there was a positive correlation between the magnitude of $\overline{\mathrm{BrO}} \cdot \frac{n_{t}(i)}{n(i)}$ and the rate of Reaction (H2). For all simulations included in the present paper a linear relation between this expression and the rate of Reaction (H2) was used. Other relations were also checked and found to be irrelevant.

The two parameterizations of wind speed and wind direction were included in the rate constant of Reaction (H2) in such a way that its daily average magnitude was left unchanged due to these parameterizations.

\subsubsection{Ozone fluxes}

Ozone fluxes were added to the basic model in addition to the two heterogeneous reactions in order to account for the entrainment of ozone fluxes at the evaporation ponds in a time resolution of $15 \mathrm{~min}$ based on $\mathrm{O}_{3}$ measurements (Sect. 3.1.1).

\subsection{Model simulations}

Simulations were performed for 3 different days in August 2001 (4, 5 and 9, Julian days-216, 217, 221) for which measurement data was available at the evaporation ponds. The measured $\mathrm{BrO}$ time series during these days were representative of the entire campaign. The days chosen for simulations were those for which no significant signs for iodine species activity were detected. Since iodine oxide species formation has been detected at the Dead Sea (Zingler and Platt, 2005) it is important to perform the simulations only on those days without expected IO presence. The various conditions used in the simulations are summarized in Table 4.

The model simulations did not include the chemistry of Reactive Chlorine Species. However, the influence of chlorine species at the Dead Sea is expected to be low relative to the contribution of bromine species due to the low $\mathrm{Cl} / \mathrm{Br}$ ratio (about 40) at the Dead Sea. This is because the production of $\mathrm{Br}_{2}$ is expected to be more efficient than the production of $\mathrm{BrCl}$ for $\mathrm{T}=<295^{\circ} \mathrm{k}$ by a factor greater than 10 (Fickert et al., 1999) and because the production of $\mathrm{Cl}$ is dominant only for a $\left[\mathrm{Cl}^{-}\right] /\left[\mathrm{Br}^{-}\right]$ratio of greater than 2000 (Behnke et al., 1999).

During the simulations, the contribution of each reaction to the formation of its products was investigated by including a chemically inert species as an additional product in the reaction. For example, Reaction (G1) appeared in the model as 
Table 4. Key of different simulation runs.

\begin{tabular}{|c|c|}
\hline Simulation & Individual conditions for calculations ${ }^{\mathrm{a}}$ \\
\hline "FULL" & Full bromine species mechanism as described in Sect. 2.1 . \\
\hline “NOB” & No bromine mechanisms included. \\
\hline "NOOZ" & $\begin{array}{l}\mathrm{No}_{3} \text { fluxes advected during RBS activity. } \mathrm{O}_{3} \text { fluxes advected only for a short time during evening when RBS } \\
\text { activity was insignificant. }\end{array}$ \\
\hline "NOHET" & No heterogeneous reactions included ${ }^{\mathrm{b}}$. \\
\hline "NOH1" & Reaction (H1) was excluded ${ }^{\mathrm{c}}$. \\
\hline "NOH2" & Reaction (H2) was excluded ${ }^{\mathrm{c}}$. \\
\hline "NWS" & $\begin{array}{l}\text { Wind speed parameterization not included for Reaction }(\mathrm{H} 2) \text {. The rate of Reaction }(\mathrm{H} 2) \text { was normalized in } \\
\text { order to obtain the same daily average value that was used in the "FULL" simulation. }\end{array}$ \\
\hline “NWD” & $\begin{array}{l}\text { Wind direction parameterization for Reaction (H2) was not included. The rate of Reaction (H2) was normalized } \\
\text { in order to obtain the same daily average value that was used in the "FULL" simulation. }\end{array}$ \\
\hline
\end{tabular}

a All simulations except for NOHET, NOH1 and NOH2 were run with a maximal $\mathrm{Br}_{2}$ flux of 10 molecules $\mathrm{cm}^{-2} \mathrm{~s}^{-1}$ normalized to the actinic flux at the area at the appropriate time. ${ }^{b}$ Simulation with maximal $\mathrm{Br}_{2}$ flux of $5 \times 10^{10}$ molecules cm ${ }^{-2} \mathrm{~s}^{-1}$ normalized to the actinic flux at the appropriate time. ${ }^{\mathrm{c}}$ Simulation with maximal $\mathrm{Br}_{2}$ flux of $10^{10}$ molecules $\mathrm{cm}^{-2} \mathrm{~s}^{-1}$ normalized to the actinic flux at the appropriate time.

$\mathrm{Br}+\mathrm{O}_{3} \rightarrow \mathrm{BrO}+\mathrm{O}_{2}+\mathrm{X}$, where $\mathrm{X}$ is an inert gas product specific to Reaction (G1). The first derivative with time of the concentration of this inert species correlates with the rate of the reaction that produces this product, and appears in this paper as $\frac{\Delta[X]}{\Delta t}$, where $\mathrm{X}$ indicates the reaction number.

In practice, this approach was mainly used in order to compare between the time series of the reaction rate, represented by the magnitude $\frac{\Delta[X]}{\Delta t}$, and the time series of the modeled concentrations of a product formed by this reaction. Once the inert species $\mathrm{X}$ is formed in the model, its concentrations can only be changed due to physical processes incorporated into the model. The same physical properties were defined for the inert species and for the product of the same reaction, to which it was compared. Therefore, the physical effect is neutralized in the comparison of the magnitude $\frac{\Delta[X]}{\Delta t}$ and the specific product to which it is being compared. This allowed for the isolation of the chemical effect from the physical effects. Another advantage of this method is that the magnitude $\frac{\Delta[X]}{\Delta t}$ is calculated with the same time resolution as the model time step.

\subsection{Field measurements}

All simulations presented here were based on a comprehensive set of atmospheric trace gas measurements and relevant meteorological parameters collected at the Dead Sea. Continuous measurements of $\mathrm{O}_{3}, \mathrm{NO}, \mathrm{NO}_{\mathrm{x}}, \mathrm{SO}_{2}$, particulate sulfates and nitrates, wind speed and direction, temperature, relative humidity, pressure and solar radiation, were conducted at the evaporation ponds using the techniques described by Matveev et al. (2001) during 2-12 August 2001 (see Fig. 1 for site locations). The differential optical absorption spectroscopy (DOAS) technique was employed to quantify $\mathrm{BrO}$ (detection limit $\leq 7 \mathrm{pptv}$ ) and $\mathrm{NO}_{2}$ (detection limit $\leq 0.5$ ppbv) (Matveev et al., 2001). The continuous measurements were performed at the western edge of the ponds, while the DOAS measurements represent the average concentrations along a $5.8 \mathrm{~km}$ light path with the light source situated due east over the evaporation ponds.

$\mathrm{O}_{3}$ was measured at the western end of the DOAS light path (Fig. 1) on the edge of the evaporation ponds. The $\mathrm{O}_{3}$ monitor was located downwind of the DOAS reflectors, with wind vector and light path directions differing by less than $20^{\circ}$. The changes in $\mathrm{O}_{3}$ concentrations were detected with a time delay of 10 to 30 min relative to the comparable changes in $\mathrm{BrO}$ levels, due to the transport of the air masses along the DOAS light path to the $\mathrm{O}_{3}$ monitor. Thus, the measurements of $\mathrm{BrO}$ and $\mathrm{O}_{3}$ represent concentrations in the same air mass at two different locations. In order to synchronize the measurements of ozone and $\mathrm{BrO}$ to the same time scale, the wind speed and direction were used to calculate the travel time along the DOAS light path, and the ozone measurements were adjusted back in time (Fig. 2a). All ozone concentrations presented in this paper have been adjusted in this way.

Supporting parameters that were not measured at the evaporation ponds site were obtained from other research campaigns performed at the Dead Sea. In Metzokei Dragot, a site some $400 \mathrm{~m}$ above the Dead Sea (see Fig. 1), $\mathrm{NO}_{\mathrm{y}}$ species $\left(\mathrm{NO}_{\mathrm{y}}=\mathrm{NO}_{\mathrm{x}}+\mathrm{HNO}_{3}+2 \mathrm{~N}_{2} \mathrm{O}_{5}+\mathrm{NO}_{3}+\right.$ organic nitrates + particulate nitrate $+\ldots$ ) were detected by the use of an appropriate converter located before the inlet of the $\mathrm{NO}_{\mathrm{x}}$ monitor. This, together with $\mathrm{NO}_{2}$ data from the DOAS, was used to calculate the $\mathrm{NOz}\left(\mathrm{NO}_{\mathrm{z}}=\mathrm{NO}_{\mathrm{y}}-\mathrm{NO}_{\mathrm{x}}\right)$ concentrations. During another campaign at the Ein Bokek site canister samples were collected and analyzed for hydrocarbons using GCMS. 


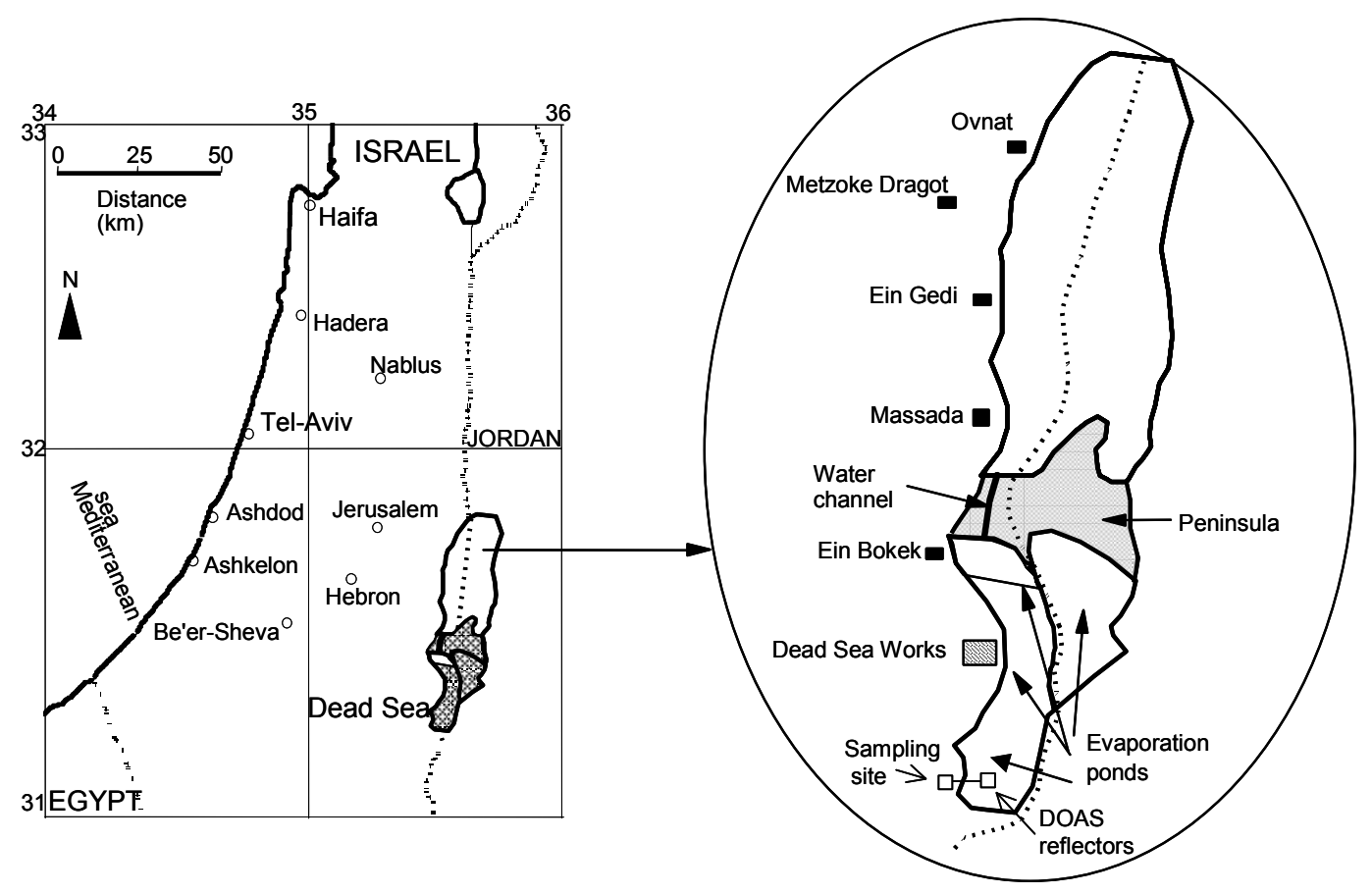

Fig. 1. Map of Israel, inset showing Dead Sea region.

\section{Results and discussion}

The measured BrO profiles at the Dead Sea are unique in their high concentrations, jagged shape, and relation to the measured ozone profile (Fig. 2a). While the basic relation between $\mathrm{BrO}$ and $\mathrm{O}_{3}$ is one of anti correlation, under certain circumstances, a positive correlation of $\mathrm{O}_{3}$ to $\mathrm{BrO}$ can be observed (Fig. 2a). The basic homogeneous model mechanism could not correctly simulate the measured $\mathrm{O}_{3}$ and $\mathrm{BrO}$ concentrations (Figs. 2a, b and 4). As described below, the present research has demonstrated that a basic description of the special RBS activity at the Dead Sea can be achieved only by the addition of two heterogeneous processes and ozone fluxes to the basic gas phase mechanism.

\subsection{Model verification}

\subsubsection{Validation of ozone profiles}

The general pattern of ozone levels measured at the evaporation ponds increased sharply at sunrise, and then began a steady decrease, reaching a minimum of nearly zero at around 11:00 a.m. This was followed by sharp increases in ozone, alternating with sharp decreases, thus forming a jagged pattern (Fig. 2a). These mid-day increases must be the result either of photochemical production or of advection from outside the area. Model simulations, without external $\mathrm{O}_{3}$ fluxes, showed that the observed increases in $\mathrm{O}_{3}$ concentrations, were not due to photochemical production, even at lower $\mathrm{O}_{3}$ destruction rates (Fig. 2b). Thus, these in-

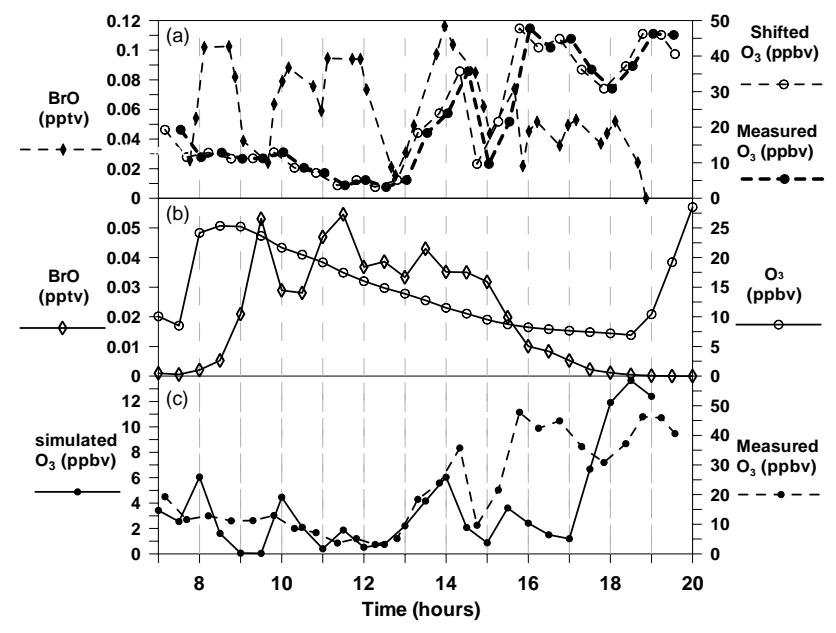

Fig. 2. Movement of ozone fluxes into the spatial region of bromine activity. (a) Measured $\mathrm{BrO}$ concentrations vs. time-shifted and not shifted $\mathrm{O}_{3}$ concentrations measured during Julian day 221. (b) $\mathrm{BrO}$ and $\mathrm{O}_{3}$ concentrations for "NOOZ" simulation. Simulated $\mathrm{BrO}$ and $\mathrm{O}_{3}$ concentrations did not match the measured levels when $\mathrm{O}_{3}$ fluxes were not added. (c) Simulated $\mathrm{O}_{3}$ concentrations vs. timeshifted measurements. It is evident that the jagged events in the $\mathrm{BrO}$ time series are associated with times when simulated $\mathrm{O}_{3}$ crosses the threshold value of $\sim 1$ to $2 \mathrm{ppb}$ (panel c).

creases must be the result of the entrainment of external air masses, containing higher $\mathrm{O}_{3}$ concentrations, into the area during periods of RBS activity. Due to the relatively small 


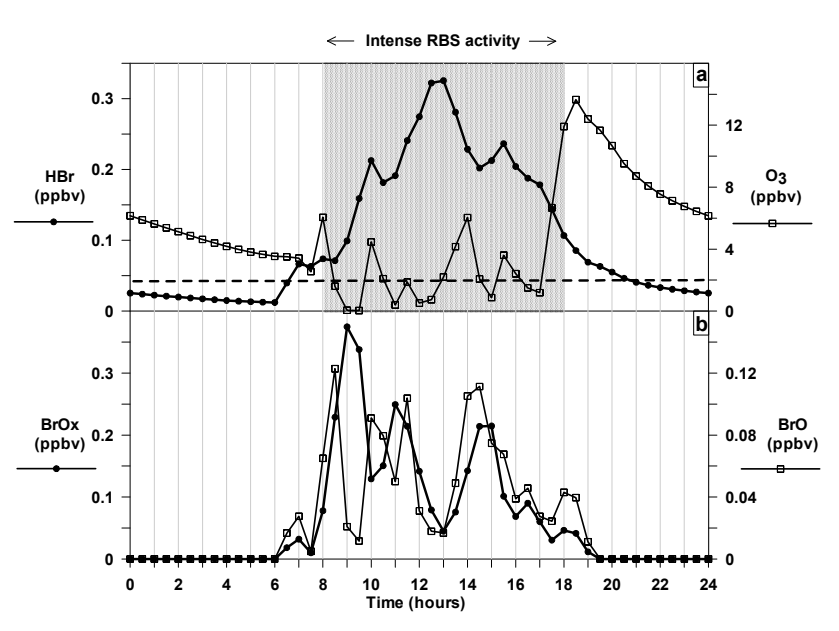

Fig. 3. The influence of $\mathrm{O}_{3}$ depletion below $\sim 1-2 \mathrm{ppbv}$ on $\mathrm{Br}$ and BrO diurnal profiles. (a) When $\mathrm{O}_{3}$ levels were dropped below $\sim 1-$ 2 ppbv (dashed line at $2 \mathrm{ppbv}$ ), concentrations of $\mathrm{HBr}$ increased, indicating an increase in the rate that $\mathrm{Br}$ undergoes termination reactions. (b) This in turn caused the decrease in $\mathrm{Br}$ and $\mathrm{BrO}$ concentrations, and hence led to lower $\mathrm{BrO}_{\mathrm{x}}$ levels.

width of the evaporation ponds at the Dead Sea (4 km EastWest), and the eastern wind flows, this entrainment is possible, occurring on a time scale of tens of minutes. Since the model used in this work is one dimensional, it cannot account for this external advection of chemical species, and it was, therefore, necessary to add horizontal $\mathrm{O}_{3}$ fluxes during the simulations (Sects. 2.1.3 and 3.2.2). The chemical process by which ozone fluxes are entrained into the evaporation ponds, their influence on the RBS activity, and their relation to $\mathrm{Br}$ concentrations are discussed in detail in Sect. 3.2.2.

The timing of the input of ozone fluxes was based on actual measured ozone in order to obtain good agreement between the trends of the simulated and measured ozone time series. The magnitude of the simulated ozone, however, was lower than the ozone concentrations measured at the edge of the ponds for two reasons: (1) the difference in ozone levels between the center and the edges of the evaporation ponds and more fundamentally, (2) adjustment limitations in the model, as described later in this section. First, the ozone concentrations measured at the edge were higher than the simulated levels representing the middle of the ponds. This is consistent with limited DOAS measurements of ozone over the evaporation ponds, showing that they were lower than those measured by the monitor at the edge of the ponds. It is likely that the edge of the evaporation ponds was influenced by air masses containing higher levels of ozone.

The more fundamental reason for the lower simulated ozone concentrations was that the changes in $\mathrm{O}_{3}$ concentrations were so frequent and severe at the Dead Sea, that they could not be captured by the model due to adjustment limitations. As described in the next paragraph, it turned out that a correct description of $\mathrm{O}_{3}$ concentrations at low levels, cross-

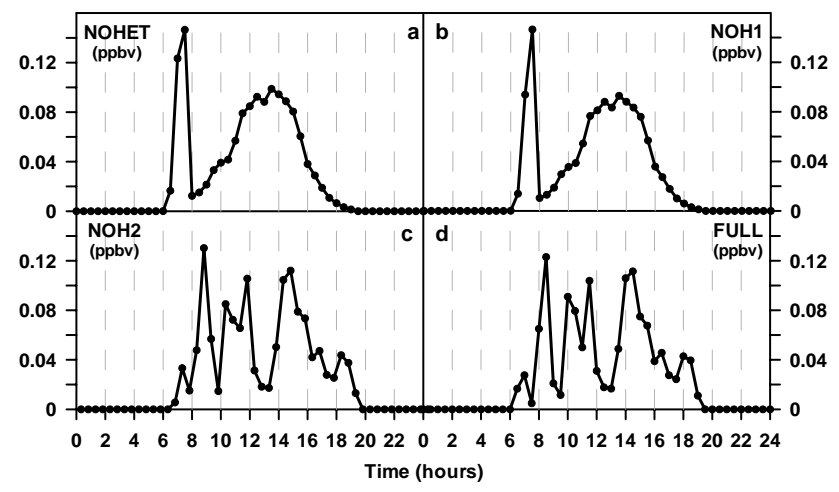

Fig. 4. Diurnal profiles of BrO obtained in different simulations (See Table 4 for the conditions of each simulation).

(a) NOHET - Heterogeneos reactions ( $\mathrm{H} 1$ and $\mathrm{H} 2$ ) are not included

(b) NOH1 - Reaction (H1) is not included

(c) $\mathrm{NOH} 2$ - Reaction (H2) is not included

(d) FULL - All reactions are included

The full treatment of the bromine chemistry suggested in this paper is incorporated only in the FULL simulation. In the plots for NOHET, NOH1, and NOH2, the $\mathrm{Br}_{2}$ flux was multiplied by $\sim 10^{9}$ (Table 4), an unrealistic value. Reaction (H1) is necessary for the structure, Reaction (H2) is necessary for the correct magnitude of $\mathrm{BrO}$ concentrations.

ing a threshold value of $\sim 1$ to $2 \mathrm{ppb}$, was the crucial factor for determining the correct $\mathrm{BrO}$ time series. It was not necessary to obtain a strict agreement for higher levels of $\mathrm{O}_{3}$, and the choice was made to obtain the best possible match for the lower ozone concentrations around the threshold value (Fig. 2c). The inclusion of these ozone fluxes in this manner, focusing on the timing of the ozone changes at low levels, gave a good match between the modeled and simulated $\mathrm{BrO}$ time series.

Figure 3 demonstrates that the frequent and severe transitions between increases and decreases in $\mathrm{BrO}$ were controlled by ozone concentrations crossing the threshold value of $\sim 1-2 \mathrm{ppb}$, as described in detail in Sect. 3.2.2. This occurred in a way that, close to the threshold level, $\mathrm{d}[\mathrm{BrO}] / \mathrm{dt}$ was positive for $\left[\mathrm{O}_{3}\right]$ above $\sim 1$ to $2 \mathrm{ppb}$, and $\mathrm{d}[\mathrm{BrO}] / \mathrm{dt}$ was negative for $\left[\mathrm{O}_{3}\right]$ below $\sim 1$ to $2 \mathrm{ppb}$. On the other hand, if the simulations were adjusted to the higher ozone levels, even large changes in ozone, $\mathrm{d}\left[\mathrm{O}_{3}\right] / \mathrm{dt}$, caused much smaller changes in $\mathrm{d}[\mathrm{BrO}] / \mathrm{dt}$, did not lead to the jagged shape of the $\mathrm{BrO}$ concentrations, and, furthermore, the simulated $\mathrm{BrO}$ time series were inconsistent with $\mathrm{BrO}$ measurements. These observations were also confirmed by the model results for the two other simulations describing RBS activity in two other days. The focus was thus placed on the trends of measured ozone concentrations, making sure that the simulated ozone concentrations were allowed to drop below the threshold level (Fig. 2c). This, together with the addition of two heterogeneous processes, led to a good agreement between simulated and measured $\mathrm{BrO}$ (Sect. 3.1.2). 


\subsubsection{Validation of $\mathrm{BrO}$ profiles}

As stated previously, even after including ozone advection into the region, the simulations could not emulate the unique $\mathrm{BrO}$ profile using only a gas phase mechanism. The present study shows that the heterogeneous decomposition of $\mathrm{BrONO}_{2}$ (Reaction $\mathrm{H} 1$ ) and the "Bromine Explosion" (Reaction $\mathrm{H} 2$ ) are not only necessary, but also sufficient to reconstruct the BrO time-series measured at the Dead Sea. This can be seen in Fig. 4, which shows simulations without Reaction (H2) (NOH2), without Reaction (H1) (NOH1), and without the two reactions (NOHET). It should be noted that the simulations, except for FULL, were initiated with a $\mathrm{Br}_{2}$ flux about $10^{9}$ times higher than normal simulation fluxes (Table 4). This $\mathrm{Br}_{2}$ flux was unrealistically high, and was necessary in order to get reasonable results in the absence of Reaction (H1) or (H2). Even though the addition of Reaction (H1) produces the correct jagged diurnal pattern of $\mathrm{BrO}$, it is only when both of the heterogeneous reactions are added together (FULL simulation) that the simulations agree with both the BrO pattern and its magnitude (Fig. 4).

The present study provides more evidence for the significant role of Reaction (H1) in the RBS activity at the Dead Sea. With the inclusion of this reaction, the mechanism was able to account for the conversion of $\mathrm{NO}_{2}$ to $\mathrm{NO}_{\mathrm{z}}$ that was frequently observed at the Dead Sea (Sect. 3.2.3). The exclusion of this reaction led to several incompatibilities between the simulations and the measurements. The formation of $\mathrm{BrONO}_{2}$ reached levels that were unrealistically high compared with those measured at the Dead Sea (Peleg et al., unpublished data, 2006), the $\mathrm{BrO}$ diurnal time series, in the absence of Reaction (H1), was also totally inconsistent with the measurements and included a significant morning peak (Fig. 4b). This peak was formed due to the increase in $\mathrm{BrONO}_{2}$ concentrations during nighttime, in the absence of Reaction (H1), followed by fast photochemical decomposition of $\mathrm{BrONO}_{2}$ during the morning (Figs. 4a and b). In addition to that, it is evident that Reaction (H1) has a dominant role in forming the jagged $\mathrm{BrO}$ time series (Fig. 4). This is because Reaction (H1) leads to a very sharp increase in the rate of $\mathrm{BrO}_{\mathrm{x}}$ formation via Cycle 3, as long as enough $\mathrm{Br}_{2}$ is produced by Reaction (H2) or by another source, as explained in Sect. 3.2.2 for Cycle 3b. This is consistent with other evidence that shows that the RBS chemistry is relatively insensitive to the timing of changes of the rate of Reaction (H2).

The simulated results were relatively insensitive to the parametrization of wind speed, suggesting that the rate of Reaction (H2) depends only weakly on concentrations of sea salt aerosols. This implies that the sea salt aerosols are not the only source of airborne $\mathrm{Br}$, and that $\mathrm{Br}$ may be released directly from the seawater or from salt pans by Reaction (H2). Similarly, the model simulations were also insensitive to the parameterization of wind direction.

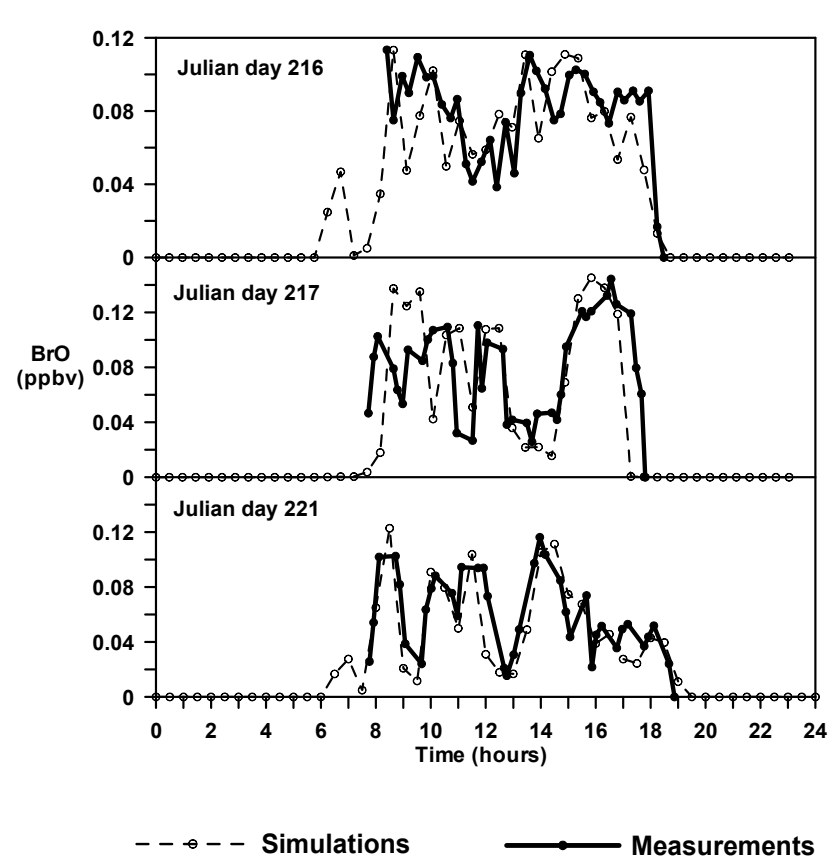

Fig. 5. Comparison between measured and simulated BrO. This graph presents only measurements of $\mathrm{BrO}$ concentrations above 20 pptv.

Following the good agreement obtained for 9 August (Julian day 221), the entire FULL simulation was performed for two other representative days, 4 and 5 August (Julian days 216 and 217). Good agreement between simulations and measurements was obtained for the three days, indicating that with the inclusion of advected $\mathrm{O}_{3}$ fluxes and two heterogeneous processes, the model is capable of sufficient accuracy and reproducibility in predicting $\mathrm{BrO}$ formation (Fig. 5). Although other heterogeneous reactions certainly take place at the Dead Sea, the present research showed that the role of the heterogeneous decomposition of $\mathrm{BrONO}_{2}$ and the "Bromine Explosion" in the RBS chemistry are expected to be most significant, based on the successful comparison of the measured and simulated $\mathrm{BrO}$ time series.

\subsection{The RBS activity at the Dead Sea}

The RBS mechanism suggested for the Dead Sea evaporation ponds area is schematically displayed in Fig. 6. The time series of some important gas phase bromine-containing species obtained during "FULL" simulation are shown in Fig. 7. Based on the simulations, the daily (06:00-20:00) average concentrations of $\mathrm{HO}_{2}$ and $\mathrm{OH}$ during RBS activity are about 2 ppt and $1 \mathrm{ppt}$, respectively. The sharp increase in the sum of bromine species begins on 06:00 a.m., at sunrise, with a small peak of $\mathrm{BrO}$ reaching about $20 \mathrm{ppt}$ due mainly to the photochemical decomposition of $\mathrm{Br}_{2}$ (Fig. 5). The increase in total $\mathrm{Br}$ lasts until 09:30 a.m. with a short decay between 07:00 a.m. and 07:30 a.m. (Fig. 7). After approximately 


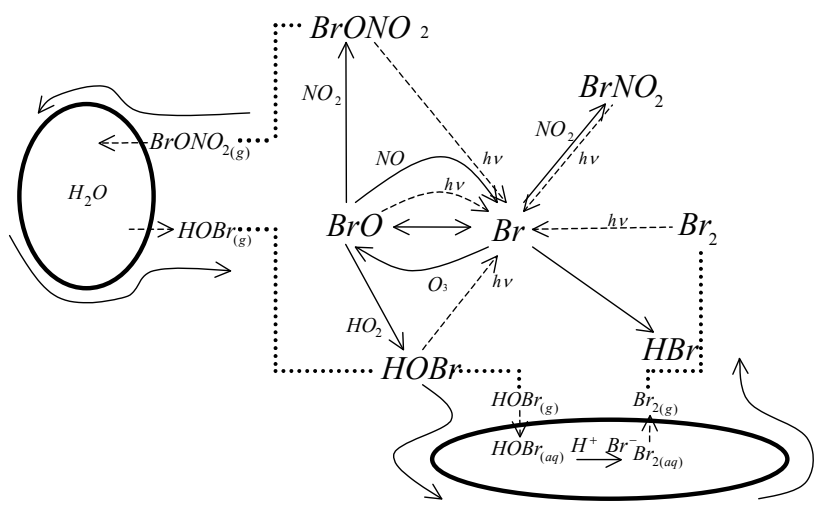

SEA SALT AEROSOL PRODUCTION

Fig. 6. Schematic description of the overall RBS mechanism that was used in the model.

09:00 a.m. until sunrise occurs again, the sum of Br tends to decrease continuously. It can be seen that, during RBS activity, BrO is not the only species that shows a jagged diurnal profile and other bromine species also exhibit a similar jagged diurnal profile.

\subsubsection{Main factors of BrOX formation at the Dead Sea}

Sea salt concentrations: The basic contributor to high RBS levels is the abundant $\mathrm{Br}^{-}$present in the Dead Sea waters. According to a laboratory study (Fickert et al., 1999) the efficiency of $\mathrm{Br}_{2}$ release by activation of $\mathrm{HOBr}$, is not expected to increase once $\mathrm{Br}^{-}$exceeds a value of $\sim 0.8 \mathrm{~mol} / \mathrm{m}^{3}$ (for $\mathrm{pH}=5.5$ and $\mathrm{T}=274^{\circ} \mathrm{K}$ ). The $\mathrm{Br}^{-}$at the Dead Sea exceeds this value by about two orders of magnitudes, while the $\mathrm{Br}^{-}$ of normal ocean water is about equal to this value. However, a previous study (Tas et al., 2005) showed an increase in both frequency and concentrations of $\mathrm{BrO}$ events towards the more concentrated salt ponds, and may indicate that the high $\mathrm{Br}^{-}$concentrations at the Dead Sea contribute to the $\mathrm{BrO}$ formation. Even so, the very high $\mathrm{Br}^{-}$content may not be solely responsible for the high $\mathrm{BrO}$ levels observed at the Dead Sea.

Photochemical reactions: Model simulations showed that the formation of $\mathrm{BrO}_{\mathrm{x}}$ is also highly dependent on photochemical reactions. This is emphasized by the similarity between the diurnal pattern of $\mathrm{BrO}_{\mathrm{x}}$ and the photochemical decomposition rates ( $\mathrm{J}$ values) of bromine species that are essential for the progress of RBS activity. The sharp increase in $\mathrm{BrO}_{\mathrm{x}}$ between 06:00 and 07:00 (Fig. 3) is mainly due to the fast increase in the rate of the photochemical decomposition of $\mathrm{Br}_{2}$, leading to a sharp decrease in $\mathrm{Br}_{2}$ concentrations (Fig. 7). As photochemical decomposition rates of the key bromine species reach near-zero values, the $\mathrm{BrO}_{\mathrm{x}}$ levels decrease sharply by about 4 orders of magnitude in only $1 \mathrm{~h}$,

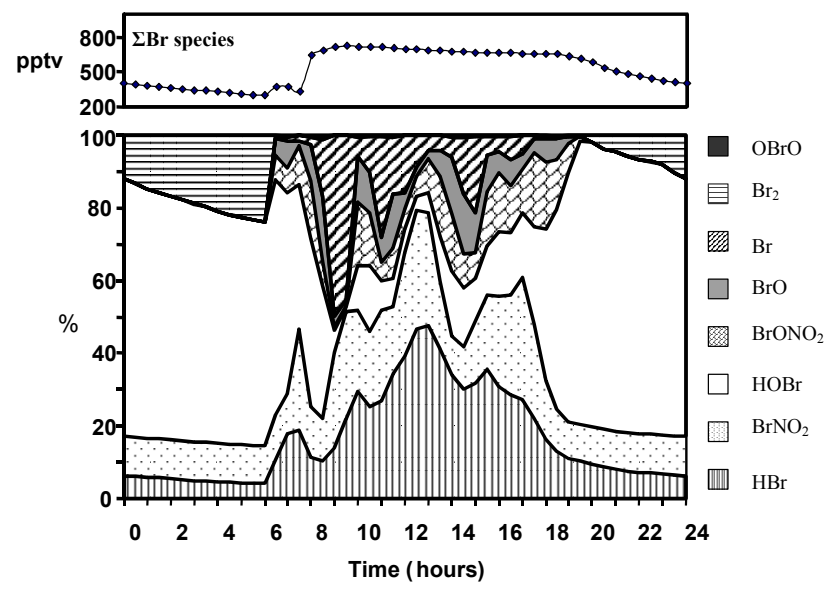

Fig. 7. Cumulative diurnal profile of significant bromine species in the gas phase. $\Sigma \mathrm{Br}$ species refers to the sum of the 8 bromine species shown in the lower panel.

between 19:00-20:00. Although they are essential to the process, these photochemical reactions are only a necessary trigger for efficient production and recycling of RBS.

Heterogeneous reactions: If the model is run without including heterogeneous Reactions (H1) and/or (H2), maximal $\mathrm{BrO}$ concentrations do not exceed $1 \mathrm{pptv}$, while the measured $\mathrm{BrO}$ levels were greater by about two orders of magnitude. As described previously, the heterogeneous processes $(\mathrm{H} 1)$ and $(\mathrm{H} 2)$ are required in order to simulate the high measured level of BrO (Sect. 3.1.2). Cycle 3, especially Cycle $3 \mathrm{~b}$ which includes these two processes, is suggested as being the chemical mechanism which promotes the extensive $\mathrm{BrO}_{\mathrm{x}}$ formation at the Dead Sea:

Cycle 3

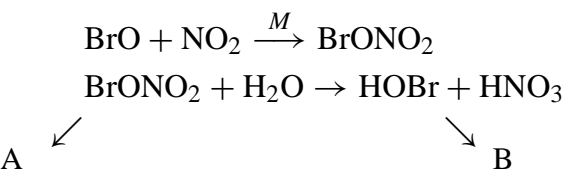

$\mathrm{HOBr} \stackrel{h v}{\longrightarrow} \mathrm{OH}+\mathrm{Br}(\mathrm{GP} 3)$

$\mathrm{HOBr}+\mathrm{H}^{+}+\mathrm{Br}^{-} \rightarrow \mathrm{Br}_{2}+\mathrm{H}_{2} \mathrm{O}(\mathrm{H} 2)$
$\mathrm{Br}_{2} \stackrel{h v}{\longrightarrow} 2 \mathrm{Br}$

$\searrow \quad \mathrm{Br}+\mathrm{O}_{3} \rightarrow \mathrm{BrO}+\mathrm{O}_{2}$

net: Cycle 3a

$\mathrm{NO}_{2}+\mathrm{H}_{2} \mathrm{O}+\mathrm{O}_{3} \stackrel{\mathrm{BrO}_{\mathrm{x}}}{\longrightarrow} \mathrm{HNO}_{3}+\mathrm{OH}+\mathrm{O}_{2}$

Cycle $3 b$

$2 \mathrm{O}_{3}+\mathrm{NO}_{2}+\mathrm{H}^{+}+\mathrm{Br}^{-} \stackrel{\mathrm{H}^{+}, \mathrm{Br}^{-}, \mathrm{BrO}_{\mathrm{x}}}{\longrightarrow} \mathrm{BrO}+\mathrm{HNO}_{3}+2 \mathrm{O}_{2}$

Cycle 3 includes the heterogeneous decomposition of $\mathrm{BrONO}_{2}$ (Reaction $\mathrm{H} 1$ ) followed either by the photodissociation of $\mathrm{HOBr}$ to $\mathrm{Br}$ (Reaction GP3) (Cycle 3a) or by the 
release of $\mathrm{Br}_{2}$ by the "Bromine Explosion" mechanism (Reaction $\mathrm{H} 2$ ) followed by the photolyzation of $\mathrm{Br}_{2}$ to yield $2 \mathrm{Br}$ (Reaction GP1) (Cycle 3b). Cycle 3 is then completed by the reformation of $\mathrm{BrO}$ from the reaction of $\mathrm{Br}$ with $\mathrm{O}_{3}$ (Reaction G1). In both Cycles $3 \mathrm{a}$ and $3 \mathrm{~b}$ the heterogeneous decomposition of $\mathrm{BrONO}_{2}$ utilizes the $\mathrm{Br}$ located in the $\mathrm{BrONO}_{2}$ reservoir to form $\mathrm{HOBr}$. In Cycle $3 b$ this formation of $\mathrm{HOBr}$ leads to the exponential production of $\mathrm{BrO}_{\mathrm{x}}$ while in $\mathrm{Cy}-$ cle $3 \mathrm{a}$ it leads to the recycling of $\mathrm{BrO}_{\mathrm{x}}$.

Another indication that Cycle $3 b$ drives RBS activity is the relation between $\mathrm{BrO}_{\mathrm{x}}$ concentrations and the rate of Reactions (H2) and (H1). First, enhanced rates of Reaction $(\mathrm{H} 2)$ leads to increases in $\mathrm{BrO}_{\mathrm{x}}$ concentrations, which reflect an exponential growth in $\mathrm{BrO}_{\mathrm{x}}$ production. Secondly, the rate of Reaction (H2), which is the rate determining step in Cycle 3b, is enhanced by Reaction (H1), leading to fast production of $\mathrm{HOBr}$ (Reaction $\mathrm{H} 1$ is more efficient by a factor of $\sim 4$ than Reaction G6). Enhanced rates of Reaction (H1) are, therefore, also associated with increases in $\mathrm{BrO}_{\mathrm{x}}$ concentrations. In addition, $\mathrm{BrO}_{\mathrm{x}}$ production is delayed relative to the rates of Reactions $(\mathrm{H} 2)$ and $(\mathrm{H} 1)$ (Fig. 8). This delay emphasizes the fact that the production of $\mathrm{BrO}_{\mathrm{x}}$ depends more on Reactions (H2) and (H1) than the reaction rates depend on $\mathrm{BrO}_{\mathrm{x}}$ levels.

$\mathrm{HOBr}$ reservoir: $\mathrm{HOBr}$ is an extremely important reservoir of RBS species at the Dead Sea, because it exists in high concentrations in this area and can lead to the formation of $\mathrm{BrO}_{\mathrm{x}}$ via Reaction (H2) (e.g., Cycle 3b) or via photochemical decomposition (e.g., Cycle 3a). The main source of $\mathrm{HOBr}$ at the Dead Sea is the heterogeneous decomposition of $\mathrm{BrONO}_{2}$ (Reaction H1). An additional significant source of $\mathrm{HOBr}$ is the reaction of $\mathrm{HO}_{2}$ with $\mathrm{BrO}$ (Reaction G6): during daytime, the $\mathrm{HOBr}$ time series follow the concentrations of $\mathrm{HO}_{2}$, with correlation factors of about $\mathrm{R}=0.45$ between 06:00 a.m. and 20:00 p.m. and $\mathrm{R}=0.85$ between 08:00 a.m. and 18:00 p.m. However, this mechanism produces $80 \%$ less $\mathrm{HOBr}$ than that formed by Reaction (H1), and is therefore much less important at the Dead Sea.

\subsection{2 $\mathrm{O}_{3}$ depletion, $\mathrm{BrO}$ profiles and $\mathrm{O}_{3}$ fluxes}

One important finding of the present study is that at the Dead Sea, $\mathrm{O}_{3}$ can occasionally function as a limiting factor in the formation and recycling of $\mathrm{BrO}_{\mathrm{x}}$ and the consequent $\mathrm{O}_{3}$ destruction. This is because the catalytic destruction of tropospheric $\mathrm{O}_{3}$ by RBS occurs by Cycles 1, 2, 3a, and $3 \mathrm{~b}$. In these cycles, the rate of $\mathrm{O}_{3}$ destruction does not depend on the rate of Reaction (G1) unless $\mathrm{O}_{3}$ levels drop below $\sim 1$ to $2 \mathrm{ppb}$. Thus, the rate of ozone destruction via $\mathrm{BrO}_{\mathrm{x}}$ production and recycling through these cycles is not normally dependent on the ozone concentrations, unless ozone levels drop below a threshold level of $\sim 1$ to $2 \mathrm{ppbv}$, as occasionally observed in the Dead Sea area. Both kinetic calculations and model simu-

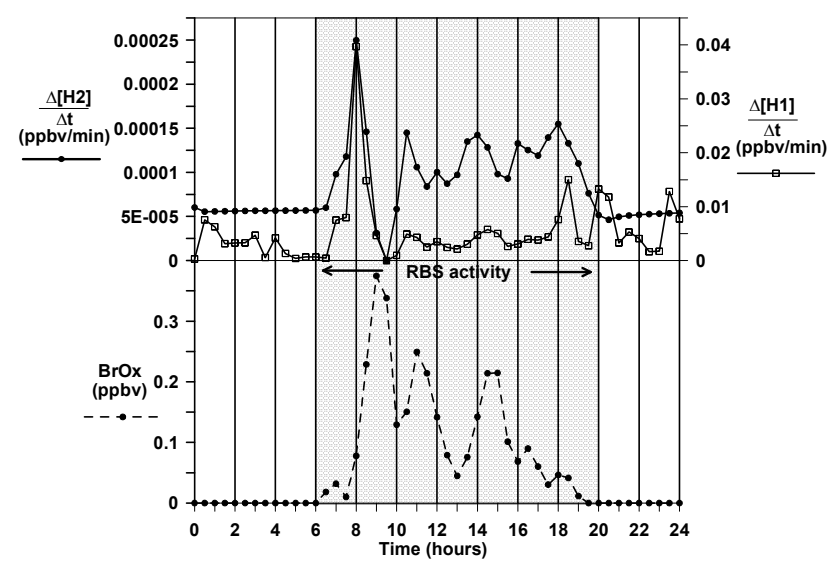

Fig. 8. The dependence of BrOx production on the heterogeneous processes. During RBS activity (shaded area) there was a correlation $(r=0.73)$ between the trends in the rates of Reactions $(\mathrm{H} 2)$ and (H1). Enhanced rates of these reactions led to increases in $\mathrm{BrO}_{\mathrm{x}}$ concentrations (which reflect $\mathrm{BrO}_{\mathrm{x}}$ production). This is because Reaction (H2) is the rate determining step in Cycle $3 b$ and is enhanced by Reaction (H1). The $\mathrm{BrO}_{\mathrm{x}}$ concentrations exhibited a correlation with these reaction rates, subject to a delay on the order of $\sim 1 / 2 \mathrm{~h}$, which is the model time resolution of the output.

lations show that below this threshold level, the rate at which $\mathrm{Br}$ reacts with ozone (Reaction G1) approaches the rates at which $\mathrm{Br}$ reacts with some of its terminators $(\mathrm{CH} 2 \mathrm{O}, \mathrm{C} 2 \mathrm{H} 2$ and $\mathrm{HO}_{2}$ ), and the bromine chemistry is driven to termination (Fig. 3).

The interaction between $\mathrm{O}_{3}$ and $\mathrm{BrO}_{\mathrm{x}}$ at the Dead Sea can be described by a periodic two stage cyclic process. The first stage of the process is an increase in $\mathrm{O}_{3}$ levels, which leads to increased $\mathrm{BrO}$ production via Reaction (G1). This in turn leads to greater $\mathrm{BrO}_{\mathrm{x}}$ production mainly through Cycle $3 \mathrm{~b}$, which then leads to the depletion of $\mathrm{O}_{3}$ during the second stage of this periodic process. During the second stage, $\mathrm{BrO}$ production via Reaction (G1) also decreases, due to a decrease in $\mathrm{O}_{3}$ concentrations. This leads in turn to lower $\mathrm{Br}$ production due mainly to an overall slower rate of Cycle $3 \mathrm{~b}$. Further decreases in $\mathrm{Br}$ occur due to the increase in the ratio $[\mathrm{Br}] /[\mathrm{BrO}]$ for lower levels of ozone (Wayne et al., 1995), which lead to a higher rate of $\mathrm{BrO}_{\mathrm{x}}$ termination mainly via Reactions (G4), (G17) and (G18). The resulting drop in $\mathrm{Br}$ concentrations weakens the $\mathrm{O}_{3}$ depletion, and eventually $\mathrm{O}_{3}$ starts to increase due to advection, initiating the periodic cycle once again.

If the $\mathrm{O}_{3}$ levels drop drastically to levels below $\sim 1$ to 2 ppbv during the second stage, further decreases in $\mathrm{Br}$ and $\mathrm{BrO}$ occur via termination reactions which lead mainly to the formation of $\mathrm{HBr}$ (Fig. 3). Please notice that the minimum in $\mathrm{Br}$ concentrations occurs around midday, simultaneously with a minimum in $\mathrm{O}_{3}$ and a maximum in $\mathrm{HBr}$ concentrations (Fig. 3a). Thus, at very low $\mathrm{O}_{3}$ levels, $\mathrm{Br}$ can be efficiently removed from the $\mathrm{O}_{3}$ depletion mechanism. This 
strengthens the motive force of transition to the first stage, and ozone can now be transported into the area resulting in higher $\mathrm{O}_{3}$ concentrations.

The change of $\mathrm{Br}$ concentrations with time, $\frac{d B r}{d t}$, appears to play an important role in controlling the $\mathrm{O}_{3}$ concentrations in the air masses which were advected into the evaporation ponds. This factor changes cyclically as a part of the periodic process described previously. The second stage in this periodic process is featured by a decrease in $\mathrm{O}_{3}$ concentrations, and a consequent decrease in $\mathrm{BrO}$ and $\mathrm{Br}$ concentrations. Thus, during the second stage of the process, $\frac{d B r}{d t}<0$ due to the $\mathrm{O}_{3}$ depletion. The depletion of $\mathrm{Br}$ concentrations resulted in an increase of advected $\mathrm{O}_{3}$ due to a lower rate of reaction with $\mathrm{Br}$. This increase in $\mathrm{O}_{3}$ due to advection is even more significant after $\mathrm{O}_{3}$ reaches levels of below $\sim 1$ to $2 \mathrm{ppbv}$, which lead to a more intense $\mathrm{Br}$ depletion, as explained above. During the first stage of this periodic process, $\mathrm{O}_{3}$ can increase by up to a few ppb. During this stage, $\frac{d B r}{d t}>0$ mainly due to the increase in the rate of reactions via Cycle $3 b$ as a result of the increase in $\mathrm{O}_{3}$ concentrations. The increase in $\mathrm{Br}$ concentrations leads, during the second stage, to a renewed decrease in $\mathrm{O}_{3}$ concentrations.

In this periodic process the decrease in $\mathrm{O}_{3}$ concentrations beneath the threshold value of 1-2 ppbv, acts as a motive force for fresh $\mathrm{O}_{3}$ fluxes to move into the evaporation ponds, initiating the production of $\mathrm{BrO}$, mainly via Cycle $3 \mathrm{~b}$. This process can explain the observed increases in $\mathrm{O}_{3}$ levels after dropping to levels of only a few ppbv, as repeatedly observed at the Dead Sea (Fig. 2a). This can also explain the repeatedly observed correlation of $\mathrm{BrO}$ with $\mathrm{O}_{3}$, obtained after the first depletion of $\mathrm{O}_{3}$ during morning hours, and is the basic cause for the jagged shape of the $\mathrm{BrO}$ profiles at the Dead Sea evaporation ponds (Figs. 2a and 5). The model simulations also indicate that the addition of $\mathrm{O}_{3}$ fluxes increases the production of $\mathrm{BrO}_{\mathrm{x}}, \mathrm{O}_{3}$ depletion rates, and paradoxically, the intensity of $\mathrm{O}_{3}$ depletions. It is possible that incoming $\mathrm{O}_{3}$ fluxes may cause similar features in the diurnal profile of $\mathrm{BrO}$ at the margins of other locations that are larger than the area under investigation in the present study, such as the polar regions.

3.2.3 The role of the heterogeneous decomposition of $\mathrm{BrONO}_{2}$ and its interaction with $\mathrm{NO}_{2}$

The NO levels measured during the field campaigns were usually very low, and frequently dropped to below detection limit ( $0.1 \mathrm{ppbv})$ during $\mathrm{BrO}$ formation periods. Additionally, the simulations showed that at these levels, the influence of NO on RBS activity was insignificant. Therefore, the role of $\mathrm{NO}$ is not discussed in this section. In contrast, the $\mathrm{NO}_{2}$ concentrations at the Dead Sea reach levels of several ppb and appear to enhance the importance of the heterogeneous decomposition of $\mathrm{BrONO}_{2}$ (Reaction $\mathrm{H} 1$ ), which occurs about $34 \%$ faster than its photochemical decomposition. At the
Dead Sea, Reaction (H1) has a significant influence on the nitrogen oxides balance.

A conversion of $\mathrm{NO}_{2}$ to $\mathrm{NO}_{\mathrm{Z}}$ during RBS activity was frequently observed at the Dead Sea, expressed by a sharp drop in $\mathrm{NO}_{2}$ levels coinciding with an equivalent increase of $\sim 1$ to $2 \mathrm{ppb}$ in $\mathrm{NO}_{\mathrm{z}}$ (Fig. 9a). Measurements performed at Metzokei Dragot (Tas et al., 2005) showed that on the average for the entire campaign, $\mathrm{NO}_{2}$ concentrations dropped to levels of below $\sim 0.1 \mathrm{ppb}$ concentrations for $\mathrm{BrO}$ levels of $\sim 30 \mathrm{pptv}$ or greater, while a corresponding increase of $\mathrm{NO}_{z}$ was detected (Fig. 9a). Similarly, simulations showed that during RBS activity, $\mathrm{NO}_{2}$ was depleted to levels of $\sim 0.1$ ppbv together with an increase of $\mathrm{HNO}_{3}$ (Fig. 9b). The depletion of $\mathrm{NO}_{2}$ during RBS activity related to the heterogeneous decomposition of $\mathrm{BrONO}_{2}$, has been reported in other field and model studies (e.g. Sander et al., 1999; Evans et al., 2003; Pszenny et al., 2004).

The formation of $\mathrm{BrONO}_{2}$ and $\mathrm{BrNO}_{2}$ on their own can account for only $\sim 0.35 \mathrm{ppbv}$ (Fig. 7) of the $\mathrm{NO}_{z}$ increase, and thus cannot explain the total observed conversion of $\mathrm{NO}_{2}$ to $\mathrm{NO}_{\mathrm{z}}$. The increase in $\mathrm{HNO}_{3}$ was shown to be anticorrelated with $\mathrm{NO}_{2}$, according to the simulations, and can account for a growth of $\sim 1 \mathrm{ppbv}$ of $\mathrm{NO}_{\mathrm{z}}$ (Fig. 9b). Thus, the formation of $\mathrm{HNO}_{3}$ at the expense of $\mathrm{NO}_{2}$ can account for the observed conversion of $\mathrm{NO}_{2}$ into $\mathrm{NO}_{\mathrm{z}}$ during bromine activity time. In the absence of Reaction (H1) (NOH1) (Fig. 9c), the levels of both $\mathrm{NO}_{2}$ and $\mathrm{HNO}_{3}$ decrease, showing that Reaction (H1) contributes significantly to the conversion of $\mathrm{NO}_{2}$ to the more stable $\mathrm{HNO}_{3}$. The effect of other gas phase reactions on the concentrations of $\mathrm{HNO}_{3}$ and $\mathrm{NO}_{2}$ (e.g., the reaction between $\mathrm{NO}_{2}$ and $\mathrm{OH}$ ) were cancelled out since they were included in all of the simulations used for this analysis. The preceding analysis provides further evidence that Reaction (H1) has a significant contribution to RBS chemistry at the Dead Sea.

\subsection{Implications for other mid-latitude areas}

This study has shown that under conditions typical of the Dead Sea, Cycle $3 b$ has a significant contribution to ozone destruction. The contribution of this cycle is proportional mainly to the concentrations of $\mathrm{BrO}$ and $\mathrm{NO}_{2}$ and to the total surface area of substrate available for the heterogeneous Reaction (H1). Thus, the absolute contribution of Cycle $3 \mathrm{~b}$ to ozone destruction is predicted to be smaller in areas with less anthropogenic activity, which are characterized by lower levels of $\mathrm{NO}_{2}$, or sulfate aerosols.

In order to evaluate the relative contribution of Cycle $3 \mathrm{~b}$ to ozone destruction in other locations, Cycle $3 \mathrm{~b}$ needs to be compared to the contributions of cycles 1 and 2 . At a first approximation, the relative importance of each of these cycles should be evaluated based on the dependence of the rate of these cycles on $\mathrm{BrO}$ concentrations, which are lower in other areas. This dependence is dictated mainly by the influence of $\mathrm{BrO}$ concentrations on the rate of the slowest reaction in 
the cycle. During daytime at the Dead Sea, Reaction (H2) is the rate limiting step in Cycle $3 \mathrm{~b}$, slower by about two orders of magnitude than Reaction (G14). Since the level of $\mathrm{BrO}$ influences the rate of Cycle $3 \mathrm{~b}$ only via Reaction (G14), the contribution of Cycle $3 b$ to $\mathrm{O}_{3}$ destruction is, on average, less than linearly dependent on $\mathrm{BrO}$ concentrations. As mentioned, Cycle 1 has a quadratic dependence on $\mathrm{BrO}$ concentrations, while the dependence of Cycle 2 is linear. Thus, under the Dead Sea conditions, the dependence of $\mathrm{BrO}_{\mathrm{x}}$ production and $\mathrm{O}_{3}$ destruction on $\mathrm{BrO}$ concentrations via $\mathrm{Cy}-$ cle $3 \mathrm{~b}$ is lower than those of cycles 1 and 2. Therefore, in the boundary layer at other mid-latitude areas under anthropogenic influence, characterized by similar levels of $\mathrm{NO}_{2}$ and sulfate aerosols and by lower BrO levels, the relative contribution of Cycle $3 b$ to $\mathrm{O}_{3}$ destruction may be similar or even higher than the contribution at the Dead Sea. However, in areas that are influenced by lower anthropogenic activity, and are characterized by lower levels of sulfate aerosols and $\mathrm{NO}_{2}$, the relative contribution of Cycle $3 \mathrm{~b}$ is predicted to be smaller than at the Dead Sea.

The same absolute and relative dependence on anthropogenic activity should be attributed to the rate of $\mathrm{BrO}_{\mathrm{x}}$ recycling via Cycle $3 \mathrm{a}$, as previously attributed to the production of $\mathrm{BrO}_{\mathrm{x}}$ via Cycle 3b. This is due to the less-than-linear dependence of this cycle on the rate of Reaction (G14), under the Dead Sea conditions, reflecting the fact that the rate of Reaction (H1) is slower by a factor of $\sim 2.5$ than the rate of Reaction (G14).

The analysis described in this paper shows that the production and recycling of $\mathrm{BrO}_{\mathrm{x}}$ as described by cycles $3 \mathrm{a}$ and $3 \mathrm{~b}$, and the consequent destruction of ozone, should be proportional to ambient concentrations of $\mathrm{NO}_{2}$ and sulfate aerosols. Thus, the contribution of the heterogeneous decomposition of $\mathrm{BrONO}_{2}$ to $\mathrm{BrO}_{\mathrm{x}}$ production should be much more efficient in the boundary layer of mid-latitude areas than in the boundary layer at polar regions. Since the levels of $\mathrm{NO}_{2}$ vary significantly with the distance from pollution sources, the influence of the heterogeneous decomposition of $\mathrm{BrONO}_{2}$ on $\mathrm{BrO}_{\mathrm{x}}$ production via Cycle $3 \mathrm{~b}$ and $\mathrm{BrO}_{\mathrm{x}}$ recycling via Cycle 3 a should be checked under different levels of $\mathrm{NO}_{2}$.

\section{Conclusions}

This paper presents a chemical mechanism that can describe the basic RBS activity at the Dead Sea. It was shown that in addition to gas phase reactions, the model must include advected ozone fluxes and two heterogeneous processes in order to duplicate the measurements. The present study indicates that the extraordinarily high $\mathrm{BrO}$ levels that were measured at the Dead Sea can only partially be explained by the high $\mathrm{Br}^{-}$content in the Dead Sea. These high levels are also caused by highly efficient heterogeneous processes of $\mathrm{BrO}_{\mathrm{x}}$ recycling and production that occur in the area. The two heterogeneous processes that were included are (1) the

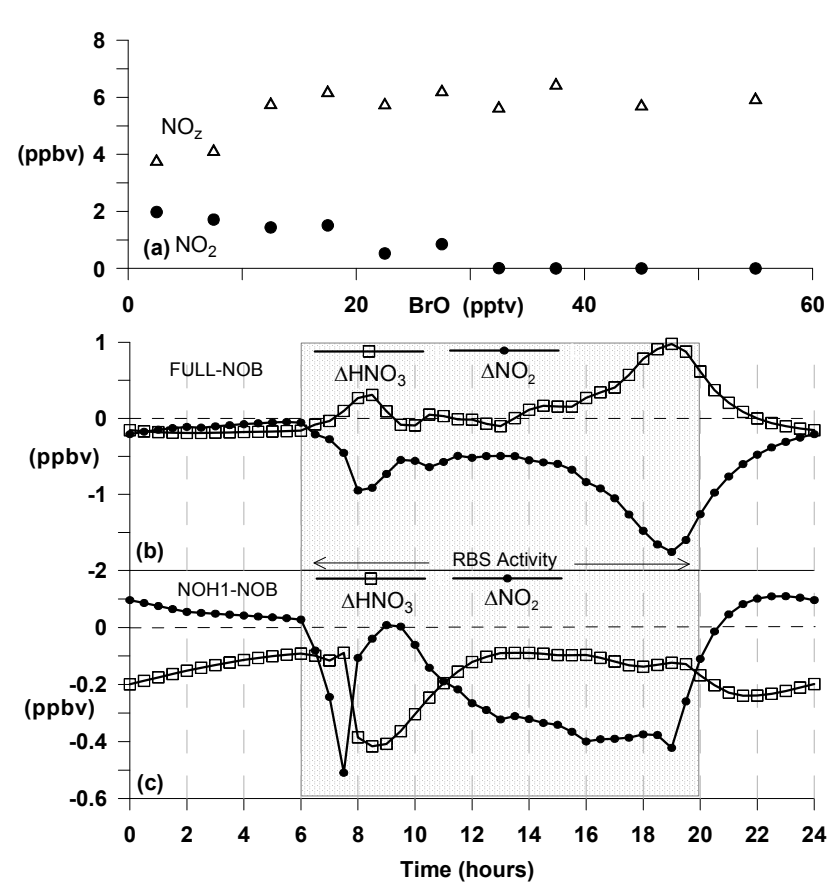

Fig. 9. Comparison of $\mathrm{NO}_{2}$ and $\mathrm{NO}_{\mathrm{z}}$ by measurements and simulations. The influence of $\mathrm{BrO}$ on $\mathrm{NO}_{2}$ and $\mathrm{NOz}$ at Metzokei Dragot is shown. Values were averaged over the entire campaign period and are presented in bins (a). $\Delta \mathrm{HNO}_{3}: \mathrm{HNO}_{3}$ concentrations during a simulation that included bromine species (i.e, "FULL" in $\mathbf{b}$ and "NOH1" in c) minus $\mathrm{HNO}_{3}$ concentrations during "NOB" simulation. $\triangle \mathrm{NO}_{2}: \mathrm{NO}_{2}$ concentrations during a simulation that included bromine species (i.e, "FULL" in b and "NOH1" in c) minus $\mathrm{NO}_{2}$ concentrations during "NOB" simulation.

release of Br into the gas phase via the "Bromine Explosion" mechanism which occurs in sea salt aerosols and (2) the decomposition of $\mathrm{BrONO}_{2}$ that occurs on the surface area of sulfate aerosols. These processes, only if included together as illustrated in Cycle 3b, can account for the efficient $\mathrm{BrO}_{\mathrm{x}}$ production and $\mathrm{O}_{3}$ destruction at the Dead Sea. Future studies of RBS chemistry should certainly investigate additional heterogeneous processes, in order to describe the RBS activity at the Dead Sea area in greater detail.

The heterogeneous decomposition of $\mathrm{BrONO}_{2}$ at the Dead Sea is an essential link in the production of $\mathrm{BrO}_{x}$ since it leads to the production of $\mathrm{HOBr} \sim 4$ times faster than its production in homogeneous gas phase (Reaction G6). The $\mathrm{HOBr}$ may then activate the release of $\mathrm{Br}$ into the gas phase by the "Bromine Explosion" mechanism, or else undergo a fast photolysis to yield $\mathrm{Br}$. It should also be noted that model simulations indicate that the release of $\mathrm{Br}_{2}$ by activation of $\mathrm{HOBr}$ may also occur directly from the sea water or salt pans and not only from the sea salt aerosols.

The present research focused on a chemical cycle which includes both the "Bromine Explosion" mechanism and the heterogeneous decomposition of $\mathrm{BrONO}_{2}$ (Cycle 3b). Under 
the Dead Sea conditions, this cycle was found to dramatically enhance the ozone destruction rate via $\mathrm{BrO}_{\mathrm{x}}$ production, and control the diurnal profiles of $\mathrm{Br}$ and $\mathrm{BrO}$. The absolute contribution of this cycle to the destruction of ozone may be less in the boundary layer at other regions characterized by lower levels of $\mathrm{BrO}$ or lower anthropogenic activity, due to lower levels of $\mathrm{NO}_{2}$ and lower sulfate aerosols levels. In these areas, both the absolute and relative contribution of the heterogeneous decomposition of $\mathrm{BrONO}_{2}$ to ozone destruction via Cycle $3 \mathrm{~b}$ is predicted to be smaller. In contrast, the relative contribution of Cycle $3 \mathrm{~b}$ may be higher in areas that are under anthropogenic influence but are characterized by lower $\mathrm{BrO}$ levels. Variations in anthropogenic activity affect Cycle 3b mainly through the levels of $\mathrm{NO}_{2}$ and, to a lesser extent, by the levels of sulfate aerosols. This is because $\mathrm{NO}_{2}$ levels are more sensitive to the distance from pollution sources. The influence of $\mathrm{NO}_{2}$ levels on the rate of the heterogeneous decomposition of $\mathrm{BrONO}_{2}$ and the consequent rate of $\mathrm{BrO}_{\mathrm{x}}$ production and ozone destruction will be presented in a later paper. This may be especially important in order to obtain a more accurate knowledge of the RBS activity at mid-latitudes.

The heterogeneous decomposition of $\mathrm{BrONO}_{2}$ leads to an increase in the concentrations of $\mathrm{HNO}_{3}$ and a decrease in the concentrations of $\mathrm{NO}_{2}$ to levels below $\sim 0.1 \mathrm{ppbv}$, thus leading to an anticorrelation between the two. This finding can account for the measured increase in $\mathrm{NO}_{z}$ concentrations that occurs simultaneously with a decrease in $\mathrm{NO}_{2}$ during RBS activity, an effect which cannot be explained solely by the formation of $\mathrm{BrONO}_{2}$ and $\mathrm{BrNO}_{2}$.

Ozone is a limiting factor to $\mathrm{BrO}_{\mathrm{x}}$ production and $\mathrm{O}_{3}$ destruction at the Dead Sea evaporation ponds, since $\mathrm{O}_{3}$ frequently reaches levels of below $\sim 1$ to 2 ppbv. The flow of $\mathrm{O}_{3}$ fluxes into the Dead Sea evaporation ponds was found to be essential for the continuation of RBS activity and $\mathrm{O}_{3}$ destruction, especially after $\mathrm{O}_{3}$ dropped below threshold levels of $\sim 1$ to $2 \mathrm{ppb}$. This flow of $\mathrm{O}_{3}$ fluxes leads to the enhancement of $\mathrm{BrO}_{\mathrm{x}}$ production and a higher rate of $\mathrm{O}_{3}$ destruction. There is a high probability that the changes in $\mathrm{Br}$ levels with time serve as a chemical regulator for the concentrations of ozone in the air masses that are advected into the ponds. This regulation is caused by the changing tendency of $\mathrm{Br}$ to react with the ozone that is transported in with the incoming air masses. It occurs in a way that promotes the entrainment of $\mathrm{O}_{3}$ fluxes as $\mathrm{O}_{3}$ levels drop below the threshold level of $\sim 1$ to $2 \mathrm{ppb}$, and inhibits the entry of ozone fluxes when ozone levels are above this threshold level. This chemical pattern accounts both for the jagged shape of the $\mathrm{BrO}$ profile and for the correlation between $\mathrm{O}_{3}$ and $\mathrm{BrO}$, as $\mathrm{O}_{3}$ reaches low enough levels. Similar features in the diurnal profile of $\mathrm{BrO}$ and its relation to $\mathrm{O}_{3}$ may also be detected at the margins of regions exhibiting RBS activity which are much larger in area than the Dead Sea.
Acknowledgements. This research was supported by a grant awarded by The Israel Science Foundation (grant 662/2004). The assistance of the Dead Sea Works (environmental division) in site logistic is gratefully appreciated. Thanks to E. Weinroth for helpful insights on atmospheric modeling.

Edited by: J. N. Crowley

\section{References}

Aranda, A., Bras, G. L., LaVerdet, G., and Poulet, G.: The BrO $+\mathrm{CH} 3 \mathrm{O} 2$ reaction: kinetics and role in the atmospheric ozone budget, Geophys. Res. Lett., 24, 2745-2748, 1997.

Andreae, T. W., Andreae, M. O., Ichoku, C., Maenhaut, W., Cafmeyer, J., Karnieli, A., and Orlovsky, L.: Light scattering by dust and anthropogenic aerosol at remote site in the Negev desert, Israel, J. Geophys. Res., 107(D2), 4008, doi:10.1029/2001JD900252, 2002.

Atkinson, R., Baulch, D. L., Cox, R. A., Crowley, J. N., Hampson, R. F., Kerr, J. A., Rossi, M. J., and Troe, J.: Summary of Evaluated Kinetic and Photochemical Data for Atmospheric Chemistry, IUPAC Subcommittee on Gas Kinetic Data Evaluation for Atmospheric Chemistry, Web Version, http://www.iupac-kinetic. ch.cam.ac.uk/, 2002.

Atkinson, R., Baulch, D. L., Cox, R. A., Crowley, J. N., Hampson, R. F., Kerr, J. A., Rossi, M. J., and Troe, J.: Summary of Evaluated Kinetic and Photochemical Data for Atmospheric Chemistry, IUPAC Subcommittee on Gas Kinetic Data Evaluation for Atmospheric Chemistry, Web Version, http://www.iupac-kinetic. ch.cam.ac.uk/, 2003.

Atkinson, R., Baulch, D. L., Cox, R. A., Crowley, J. N., Hampson, R. F., Kerr, J. A., Rossi, M. J., and Troe, J.: Summary of Evaluated Kinetic and Photochemical Data for Atmospheric Chemistry, IUPAC Subcommittee on Gas Kinetic Data Evaluation for Atmospheric Chemistry, Web Version, http://www.iupac-kinetic. ch.cam.ac.uk/, 2004.

Barrie, L. A., Bottenheim, J. W., Schnell, R. C., Crutzen, P. J., and Rasmussen, R. A.: Ozone destruction and photochemical reactions at polar sunrise in the lower Arctic atmosphere, Nature, 334, 138-141, 1988.

Bedjanian, Y., Riffault, V., Le Bras, G., and Poulet, G.: Kinetics and Mechanism of the $\mathrm{OH}$ and $\mathrm{OD}$ Reactions with BrO, J. Phys. Chem. A, 105, 6154-6166, 2001.

Behnke, W., Elend, M., Kruger, U., and Zetzsch, C.: The Influence of $\mathrm{NaBr} / \mathrm{NaCl}$ Ratio on the $\mathrm{Br}$-Catalysed Production of Halogenated Radicals, J. Atmos. Chem., 34, 87-99, 1999.

Beine, H. J., Jaffe, D. A., Stordal F., Engardt, M., Solberg, S., Schmidbauer, N., and Holmen, K.: NOx during ozone depletion events in the arctic troposphere at NY-Alesund, Svalbard, Tellus, 494, 556-565, 1997.

Biazar, A. P.: The role of natural nitrogen oxides in ozone production in the southern environment, Dissertation, The Department of Atmospheric Sciences, The University of Alabama in Huntsville, 1995.

Bloss, W. J., Rowley, D. M., Cox, R. A., and Jones, L. J.: Rate coefficient for the $\mathrm{BrO}+\mathrm{HO} 2$ raction at $298 \mathrm{~K}$, Phys. Chem. Chem. Phys, 3639-3647, 2002.

Evans, M. J., Jacob, D. J., Atlas, E., Cantrell, C. A., Eisele, F., Flocke, F., Fried, A., Mauldin, R. L., Ridley, B. A., Wert, B., 
Talbot, R., Blake, D., Heikes, B., Snow, J., Welega, J., Weinheimer, A. J., and Dibb, J.: Coupled evolution of BrOX-ClOXHOX-NOX chemistry during bromine-catalyzed ozone depletion events in the arctic boundary layer, J. Geophys. Res., 108(D4), 8368, doi:10.1029/2002JD002732, 2003.

Erlick, C. and Frederick, E.: Effects of aerosols on the wavelength dependence of the atmospheric transmission in the ultraviolet and visible 2. Continental and urban aerosols in clear skies, J. Geophys. Res., 103(D18), 23 275-23 285, 1998.

Fan, S.-M. and Jacob, D. J.: Surface ozone depletion in Arctic spring sustained by bromine reactions on aerosols, Nature, 359, 522-524, 1992.

Fickert, S., Adams, J. W., and Crowley, J. N.: Activation of Br2 and $\mathrm{BrCl}$ via uptake of $\mathrm{HOBr}$ onto aqueous salt solutions, J. Geophys. Res., 04(D19), 23 719-23 727, 1999.

Formenti, P., Andreae, M. O., Andreae, T. W., Ichoku, C., Schebeske G., Kettle, J., Maenhaut, W., Ptasinsky, J., Karnieli A., and Leliveld, J.: Physical and chemical characteristics of aerosols over the Negev Desert (Israel) during summer 1996, J. Geophys. Res., 106(D5), 4871-4890, 2001.

Gilles, M. K., McCabe, D. C., Burkholder, J. B., and Ravishankara, A. R.: Measurement of the Rate Coefficient for the Reaction of OH with BrO, J. Phys. Chem. A., 105, 5849-5853, 2001.

Gong, S. L., Barrie, L. A., and Blanchey, J.-P.: Modeling sea-salt aerosols in the atmosphere 1. Model development, J. Geophys. Res., 102(D3), 3805-3818, 1997.

Gras, J. L. and Ayers, G. P.: marine aerosol at southern midlatitudes, J. Geophys. Res., 88(C15), 10 661-10 666, 1983.

Hanson, D. R. and Ravishankara, A. R.: Heterogeneous chemistry of Bromine species in sulfuric acid under stratospheric conditions, J. Geophys. Res., 22(4), 385-388, 1995.

Hanson, D. R., Ravishankara, A. R., and Lovejoy, E. R.: Reaction of $\mathrm{BrONO}_{2}$ with $\mathrm{H}_{2} \mathrm{O}$ on submicron sulfuric acid aerosol and implications for the lower stratosphere, J. Geophys. Res., 101(D4), 9063-9069, 1996.

Harry, S., Peter, K., and Ruggaber, A.: Uncertaities in modeled UV irradiancesdue to limited accuracy and availability of input data, J. Geophys. Res., 102(D8), 9419-9429, 1997.

Harwood, M. H. and Burkholder, J. B.: Photodissociation of $\mathrm{BrONO}_{2}$ and $\mathrm{N}_{2} \mathrm{O}_{5}$ : Quantum yields for $\mathrm{NO}_{3}$ production at 248 , 308, and 352.5 nm, J. Phys. Chem. A., 102(8), 1309-1317, 1998.

Hausmann, M. and Platt, U.: Spectroscopic measurement of bromine oxide and ozone in the high Arctic during Polar Sunrise Experiment 1992, J. Geophys. Res., 99(25), 399-413, 1994.

Hebestreit, K., Stutz, J., Rosen, D., Matveev, V., Peleg, M., Luria, M., and Platt, U.: First DOAS Measurements of Tropospheric Bromine Oxide in Mid Latitudes, Science, 283, 55-57, 1999.

Honninger, G., Bobrowski, N., Palenque, E. R., Torrez, R., and Platt, U.: Reactive bromine and sulfur emissions at Salar de Uyuni, Bolivia, Geophys. Res. Lett., 31, L04101, doi:10.1029/2003GL018818, 2004.

Kreher, K., Johnston, P. V., Wood, S. W., Nardi, B., and Platt, U.: Ground-based measurements of tropospheric and stratospheric $\mathrm{BrO}$ at Arrival Heights ( $\left.78^{\circ} \mathrm{S}\right)$, Antarctica, Geophys. Res. Lett., 24(23), 3021-3024, 1997.

Leser, H., Honinger, G., and Platt, U.: Max-DOAS measurements of $\mathrm{BrO}$ and $\mathrm{NO}_{2}$ in the marine boundary layer, Geophys. Res. Lett., 31, 1537, doi:10.1029/2002GL015811, 2003.

$\mathrm{Li}, \mathrm{Z}$. and Tao, Z.: A kinetic study on reactions of $\mathrm{OBrO}$ with $\mathrm{NO}$,
OClO, and ClO at 298 K, Cem. Phys. Lett., 306, 17-123, 1999.

Madronich, S. and Flocke, S.: The role of solar radiation in atmospheric chemistry, in: Handbook of Environmental Chemistry, edited by: Boule, P., Springer-Verlag, Heidelberg, 1-26, 1998.

Matveev, V., Hebestreit, K., Peleg, M., Rosen, D. S., Tov-Alper, D., Stutz, J., Platt, U., Blake, D., and Luria, M.: Bromine OxideOzone interaction over the Dead Sea, J. Geophys. Res., 106, D10, 10375-10387, 2001.

McNider, R. T. and Pielke, R. A.: Diurnal boundary-layer development over sloping terrain, J. Atmos. Sci., 38, 2198-2212, 1981.

Michalowski, B. A., Francisco, J. S., Li, S. M., Barrie, L. A., Bottenheim, J. W., and Shepson, P. B.: A computer model study of multiphase chemistry in the Arctic boundary layer during polar sunrise, J. Geophys. Res., 105, 15 131-15 145, 2000.

Mozurkewich, M.: Mechanisms for the release of halogens from sea-salt particles by free radical reactions, J. Geophys. Res, 100(D7), 14 199-14 207, 1995.

Murayama, S., Nakazawa, T., Tanaka, M., Aoki, S., and Kawaguchi, S.: Variations of tropospheric ozone concentrations over Syowa Station, Antarctica, Tellus, 44B, 262-272, 1992.

Niemi, T. M., Ben-Avraham, Z., and Gat, J. R.: The Dead Sea: The Lake and Its Setting, Oxford Monogr. Geol. Geophys., vol. 36, Oxford Univ. Press, New York, 1997.

Platt, U. and Honninger, G.: The role of halogen species in the troposphere, Chemosphere, 52, 325-358, 2003.

Platt, U. and Moortgat, G. K.: Heterogeneous and Homogeneous Chemistry of Reactive Halogen Compounds in the Lower Troposphere, J. Atmos. Chem., 34, 1-8, 1999.

Pszenny, A. A. P., Moldanova, J., Keene, W. C., Sander, R., Maben, J. R., Martinez, M., and Crutzen, P. J.: Halogen cycling and aerosol $\mathrm{pH}$ in the Hawaiian boundary layer, Atmos. Chem. Phys., 4, 147-168, 2004, http://www.atmos-chem-phys.net/4/147/2004/.

Ridley, B. A. and Orlando, J. J.: Active Nitrogen Surface Ozone Depletion Events at Alert during Spring 1998, J. Atmos. Chem., 44, 1-22, 2003.

Ruggaber, A., Dulgi, R., and Nakajima, T.: Modelling Radiation Quantities and Photolysis Frequencies in the Troposphere, J. Atmos. Chem., 18, 171-210, 1994.

Sander, R. and Crutzen, P. J.: Model study indicating halogen activation and ozone destruction in polluted air masses transported to the sea, J. Geophys. Res., 101(D4), 9121-9138, 1996.

Sander, R., Rudich, Y., von Glasow, R., and Crutzen., P. J.: The role of $\mathrm{BrNO}_{3}$ in marine tropospheric chemistry: A model study, Geophys. Res. Lett., 26(18), 2857-2860, 1999.

Schwander, H., Koepke, P., and Ruggaber, A.: Uncertainties in modeled UV irradiances due to limited accuracy and availability of input data, J. Geophys. Res., 102, 9419-9429, 1997.

Stutz, J., Hebestreit, K., Alicke, B., and Platt, U.: Chemistry of halogen oxides in the troposphere: comparison of model calculations with recent field data, J. Atmos. Chem., 34, 65-85, 1999.

Stutz, J., Ackermann, R., Fast, J. D., and Barrie, L.: Atmospheric reactive chlorine and bromine at the Great Salt Lake, Utah, Geophys. Res. Lett., 29, 1380,doi:10.1029/2002GL014812, 2002.

Sverdrup, H. U., Johnson, M. W., and Fleming, R. H.: The Oceans, Their Physics, Chemistry and General Biology, Prentice-Hal, Englewood Cliffs, N. J., 1942.

Tang, T. and McConnell, J. C.: Autocatalytic release of bromine from Arctic snow pack during polar sunrise, Geophys. Res. Lett., 
23(19), 2633-2636, 1996.

Tas, E., Matveev, V., Zingler, J., Luria, M., and Peleg, M.: Frequency and extent of ozone destruction episodes over the Dead Sea, Israel, Atmos. Environ., 37(34), 4769-4780,2003.

Tas, E., Peleg, M., Matveev, V., Zingler, J., and Luria, M.: Frequency and extent of bromine oxide formation over the Dead Sea, J. Geophys. Res., 110(D11), D11304, doi:10.1029/2004JD005665, 2005.

Trainer, M., Williams, E. J., Parish, D. D., Buhr, M. P., Allwine, E. J., Westberg, H. H., Fehsenfeld, F. C., and Liu, S. C.: Models and observations of the impact of natural hydrocarbons on rural ozone, Nature, 329, 705-707, 1987.

Tuckermann, M., Ackermann, R., Golz, C., Lorenzen-Schmidt, H., Senne, T., Stutz, J., Trost, B., Unold, W., and Platt, U.: DOAS-Observation of Halogen Radical-catalysed Arctic Boundary Layer Ozone Destruction During the ARCTOC-Campaigns 1995 and 1996 in Ny-Alesund, Spitsbergen, Tellus, 49B, 533$555,1997$.

Vogt, R., Crutzen, P. J., and Sander, R.: A mechanism for halogen release from sea-salt aerosol in the remote marine boundary layer, Nature, 383, 327-330, 1996.
Von Glasow, R., Sander, R., Bott, A., and Crutzen, P. J.: Modeling halogen chemistry in the marine boundary layer 1 . Cloud-free MBL, J. Geophys. Res., 107(D17), 4341-4352, 2002.

Von Glasow, R., von Kuhlman, R., Lawrence, M. G., Platt, U., and Crutzen, P. J.: Impact of reactive bromine chemistry in the troposphere, Atmos. Chem. Phys., 4, 2481-2497, 2004, http://www.atmos-chem-phys.net/4/2481/2004/.

Wanger, A., Peleg, M., Sharf, G., Mahrer, Y., Dayan, U., Kallos, G., Kotroni, V., Lagouvardos, K., Varinou, M., Papadopoulos, A., and Luria, M.: Some observational and modeling evidence of long-range transport of air pollutants from Europe toward Israeli coast, J. Geophys. Res., 105(D6), 7177-7186, 2000.

Wayne, R. P., Poulet, G., Biggs, P., Burrows, J. P., Cox, R. A., Crutzen, P. J., Haymann, G. D., Jenkin, M. E., Bras, G. L., Moortgat, G. K., Platt, U., and Schindler, R. N.: Halogen oxides: radicals, sources and reservoirs in the laboratory and in the atmosphere, Atmos. Environ., 29, 2675-2884, 1995.

Zingler, J. and Platt, U.: Iodine oxide in the Dead Sea Valley: Evidence for inorganic sources of boundary layer IO, J. Geophys. Res., 110, D07307, doi:10.1029/2004JD004993, 2005. 